

\section{Bir Meta-Sentez Çalışması: Öğreticilerin Gözünden 4-6 Yaş Kur'an Kursları}

\section{Özet}

Bu çalışmanın temel amacı, Diyanet Isşleri Başkanlığı'nın (DiB) Eğitim Hizmetleri Genel Müdürlüğü'ne bağlı olarak faaliyet yürüten 4-6 yaş grubu Kur'an Kurslarında görev yapan öğreticiler ile yapılan nitel çalıșmaların ele alınması ve bu çalıșmalara yansiyan öğretici görüșlerinin bir bütün halinde değerlendirilerek bu kurslara ilişskin genel bir çerçevenin ortaya konulmasıdır. Araştırmada metasentez yöntemi kullanılmıș, bu yöntemin işlem basamaklarına uygun olarak veri toplama, veri analizi, geçerlik ve güvenirlik sağlanmaya çalışılmıştır. Araștırmanın çalışma grubunu 4-6 yaş grubu Kur'an Kursu öğreticileri ile yapılan görüșme ve mülakata dayalı nitel desenli çalışmalar oluşturmaktadır. Bu çalışmaların bulguları incelenmiş ve çeşitli kodlar elde edilmiş, daha sonra da bu kodlar birleştirilerek temalar belirlenmiş̧ir. Kodlar program geliştirme öğeleri ve yapısal sorunlar şeklinde iki tema altında analiz edilmiştir. Program geliştirme öğelerine iliş̧kin tema kapsamında öğretim programının amaç, içerik, eğitim durumları ve ölçme-değerlendirme unsurlarına dair öne çıkan öğretici görüşleri incelenmiștir. Bu temaya ilişkin olarak öncelikle öğreticilerin öğretim programı ile ilgili yeterli farkındalığa sahip olmadıkları görülmüştür. Bununla beraber öğreticilerin program içeriğini oldukça yoğun buldukları, bu programın uygulanması sürecinde öğrenci seviyesinin așıldığına dikkat çekmişlerdir. Öte yandan özelde ögrretim sürecini planlama, yönetme ve ölçme ve değerlendirme aşamalarında, genelde de pedagojik formasyonun bütününde öğreticilerin çeşitli eksikliklere sahip oldukları sonucuna ulaşılmıştır. Bununla beraber temel alan bilgisi ile ilgili konularda da eksiklikler vurgulanmış, ögreticilerin alan bilgisine ilişsin yeterlik düzeylerine iliş̧in çeşitli ihtiyaçların mevcut olduğu ortaya çıkmıștır. Öğreticilerin pedagojik formasyon ve alan bilgisine dair sahip oldukları eksikliklerinin farkında olmalarının yanı sıra çeșitli eğitim etkinlikleriyle bu eksikliklerinin giderilmesi hususunda istekli oldukları da öne çıkmış, bu anlamda çeşitli iyileştirme faaliyetlerinin önünün açık olduğu da görülmüștür. Yapısal sorunlara ilișkin temaya gelindiğinde, bu tema altında kursa kabul yaşı, ögretimin paydaşları, idarecilerle yaşanan problemler ve kursların mevcut fiziksel koșullarından kaynaklı sorunların öne çıktığı tespit edilmiştir. Bu sorunlara bağlı olarak öncelikle henüz 4 yaşındaki çocukların bu kurslara kabul edilmesinin problem teşkil ettiği, mevcut programın bu yaşın gelişimsel seviyesine hitap etmesi noktasında problemlerin var olduğu ortaya çıkmıştır. Ayrıca kurslara devam eden 4, 5 ve 6 yaşındaki çocukların gelişim basamaklarına veya yaşlarına uygun bir șekilde kategorize edilmeksizin eșit kabul edilerek aynı eğitim ortamında, aynı öğretim programına bağlı olarak eğitim görmelerinin problem teșkil ettiği ve hedeflere ulașma noktasında aksakllklar ortaya çıkardığı vurgulanmıştır. Bununla beraber öğreticiler, yardımcı personel ihtiyacına da dikkat çekmiş, kurslardaki mevcut öğretici eksikliğinin yanı sıra bu kurslarda psikolojik danışman, rehber öğretmen ve hizmetli personellerin de istihdam edilmesi gerektiğine ișaret etmişlerdir. Öğreticilerin, sorunların giderilmesi hususunda bağlı bulundukları idari birimlerle iletişsim problemi yaşadıklarına ilişsin bulgular da ortaya çıkmıştır. Öte yandan kursların mevcut fiziksel koşullarına iliş̧in problemlere de işaret edilmiş, bu koşulların söz konusu yaş aralığında bulunan çocukların ihtiyaçları göz önünde bulundurularak oluşturulması ve iyileştirilmesi gerektiği vurgulanmıştır. Araştırmada elde edilen bulgular ve sonuçlar çerçevesinde öğretim sürecine yönelik mevcut sorunların giderilmesinde kaynak program olan ilahiyat fakültelerinin program ve bölüm tartışmalarından ayrı düşünülemeyeceği, yüksek din öğretimine ilişkin program önerilerinin 4-6 yaş grubu Kur'an Kursları için de önem arz edebileceği konusu üzerinde durulmuștur. İlahiyat programının yanı sıra DiB'in mevcut pozisyonunun konuyla ilgili şartların iyileștirilmesi yönündeki engellere de işaret edilmiştir. Araştırma sürecinde mevcut olan temalardan elde edilen bulgular ve ulaşılan sonuçlara bağlı olarak hem Dỉ, hem de konuya ilgi duyan araştırmacılar için çeşitli öneriler geliştirilmiştir.

Anahtar Kelimeler: Din Eğitimi, 4-6 Yaş Grubu Kur'an Kursu, Diyanet Işsleri Başkanliğı, Meta-Sentez. 


\section{A Meta-Synthesis Study: Qur'an Courses For 4-6 Years From The Eyes of Teachers}

\section{Summary}

The main purpose of this study is to examine the qualitative studies conducted with the teachers working in the Qur'an Courses for the 4-6 age gruop operating under the General Directorate of Educational Services for the Presidency of Religious Affairs and to gather the views of the teachers reflected in this studies as a whole and to present a general framework for these courses. The metasynthesis method was used in the research and data collection, analysis, validity and reliability were tried to be ensured in accordance with the process steps of this method. The study group of the research consists of the qualitative studies based on interviews with course teachers in the 4-6 age group. Findings of these studies were examined and various codes were obtained and then themes were determined by combining these codes. The codes were analysed under two themes as program development items and structural problems. Within the scope of the first theme, the prominent views of the teachers on the purpose, content, educational status and measurement and evaluation elements of the curriculum were examined. Firstly, it was seen that, teachers did not have enough awareness about the curriculum. However, teachers found the content of the program quite intense, and student level was exceeded during the implementation of this program. And it has been concluded that, teachers have various deficiencies in planning, management, measurement-evaluation stages of teaching process in particular and in the whole of pedagogical formation in general. However, deficiencies in subjects releated to basic content knowledge were emphasized and it was revealed that there were various needs regarding the proficiency levels of teachers regarding content knowledge. In addition that, teachers are aware of their shortcomings in these subjects and they are willing to eliminate these deficiencies with various educational activities, and in this sense, it has been seen that the way for various improvement activities is clear. When it comes of the theme of structural problems, it has been determined under these theme, age of admission of the course, stakeholders of the education, problems experienced with the administrators and problems arising from the current physical conditions of the courses. Due to these problems it has been revealed that, the admission the children who are only 4 years old to these courses poses the problem, and there are problems in adressing the developmental level of current program at these age. In addition, 4, 5 and 6 year old children attending birds were considered equal without being categorized according to their development stages and age, and it was emphasized that their education in the same educational environment, depending on the same curriculum, poses a problem and causes some problems in reaching the goals. And the teachers also drew attention to the need for auxiliary personnel, and pointed out that, psychological counselors, guidance teachers and service personnel should be employed in these courses. In addition, teachers have communication problems with the administrative units. On the other hand, the problems related to the existing physical conditions of the courses were also pointed out and these conditions should be created and improved considering the needs of the children in the mentioned age range. Withing the framework of the findings, it was emphasized that the divinity faculties, which are the source of program, cannot be considered seperately from the program and deparment discussions, and that the program proposals for higher religious education may be important for these courses. In addition to the divinity program, the obstacles of the current position of the Presidency of Religious Affairs to improve conditions were also pointed out. Various suggestions have been developed for both Presidency and researches who are interested in subject, depending on the findings obtained from the themes.

Keywords: Religious Education, Qur'an Courses For 4-6 Ages, Presidency of Religious Affairs, MetaSynthesis.

\section{Giriş}

İnsanoğlu, aşkın olana bağlanma, zor anlarında aşkın olandan medet bekleme, dolayısıyla inanma duygusuna doğuștan sahiptir. Bu durum Kur'an'da ${ }^{1}$ ve ha-

1 "Rabbin âdemoğullarından -onların sırtlarından- zürriyetlerini alıp bunları kendileri hakkındaki şu sözleşmeye tabi tutmuştu: ben sizin rabbiniz değil miyim? 'Elbette ki öyle! Tanıklık ederiz' dediler. 
dislerde ${ }^{2}$ vurgulanmasının yanı sıra, dinî-psikolojik bir tespit olarak da literatürde mevcuttur. Bu tespitler arasında insanın doğuştan boş bir levha olarak gelmeyip özellikle inanca yönelik bazı kabiliyet, beklenti ve ihtiyaçlarla donanımlı olduğu hususu ${ }^{3}$ öne çıkmakla birlikte, inancın ve bazı dinî tecrübelerin insan beyninde genetik bir hareketliliğe yol açtığı yönünde nöro-biyo-psikolojik vurgular ${ }^{4} \mathrm{da}$ mevcuttur. Dolayısıyla inanç, din, ibadet ve bunlarla bağlantılı konu ve kavramlar, insanı doğuştan kuşatmış ve insanın varlığı ile bütünleşmiştir. Doğuştan beri birey ile beraber olan inanç duygusunun yaşam içinde anlam kazanabilmesi, sağlıklı bir gelişim seyri içerisinde devam etmesi noktasında verilen eğitimin de önemli fonksiyonu vardır. ${ }^{5}$

Gerek insanın kalıtsal olarak sahip olduğu inanç ile hayatı boyunca hemhâl olması, gerekse bu inancın sağlıklı bir şekilde gelişmesi ve istenen mihverde seyretmesi için çocuklara yönelik dinî eğitim girişimlerinin tarihi, ilk dönemlere kadar geri götürülebilmektedir. İslam eğitim tarihine bakıldığında, Hz. Peygamber zamanından itibaren çocukların eğitiminin önemsendiği ve bu eğitim için kurumların oluşturulduğu görülmektedir. İslam eğitim tarihinin Hz. Peygamber ve Rașid halifeler dönemini kapsayan ilk evresinde çocuklara okuma-yazma ve temel dini bilgilerin eğitiminin verildiği 'Küttab' isimli mahalle mektepleri tesis edilmiştir. ${ }^{6}$ İlerleyen süreçte Müslümanların devlet kurması, medrese ismi verilen müşahhas yükseköğretim kurumlarının ortaya çıkmasıyla çocuk eğitimi yine ihmal edilmemiş, üst bir eğitim kurumuna geçiş aşaması olarak 'Mekteb' ismi ile varlığını korumuştur. ${ }^{7}$ Çocukların eğitimi için müstakil kurumlar olan mektepler, 'Sıbyan Mektebi' özel ismi ile Osmanlı döneminde de varlığını sürdürmüş, yazı ve temel dini bilgilerin yanı sıra yer yer dinler tarihi, sarf, nahiv, ahlak ve aritmetik gibi bir program

Böyle yaptık ki kıyamet gününde 'bizim bundan haberimiz yoktu' demeyesiniz!” Diyanet İşleri Başkanlığı Kur'an-ı Kerîm, (Erişim 29 Eylül 2020), A’raf 7/172; “O halde sen hanîf olarak bütün varlığınla dine, allah insanı hangi fitrat üzerine yaratmışsa ona yönel! Allah'ın yaratmasında değişme olmaz, işte doğru din budur; fakat insanların çoğu bilmezler" Diyanet İşleri Başkanlığı Kur'an-ı Kerîm, (Erişim 29 Eylül 2020), Rûm 30/30.

2 "Bütün doğan çocuklar islam fitratı üzerine doğar. Sonradan anne ve babaları onları ya Yahudileştirir ya Hıristiyanlaştırır ya da Mecusileştirir.” Ebu Abdillah Muhammed B. İsmail el-Buhârî, Sahîhu'lBuhârî (Dımaşk: Dâru İbn Kesîr, 2002), "Cenâiz", 79 (No.1359); Ebü'l-Hüseyn Müslim B. El-Haccâc Müslim, Sahîhu Müslim (Riyad: Daru's-Selam, 2000), "Kader”, 6755; Süleyman B. El-Eş'as B. İshak B. Beşîr El-Ezdî Es-Sicistânî Ebû Dâvûd, Süneni Ebî Dâvûd, thk. Raid B. Sabri İbn Ebî 'Alfe (Riyad: Daru’lHadara, 2015), "Sünnet”, 17 (No. 4714).

3 Hayati Hökelekli, Din Psikolojisi (Ankara: Türkiye Diyanet Vakfı Yayınları, 1998), 124; Kerim Yavuz, Çocukta Dinî Duygu Ve Düşüncenin Gelişmesi (İstanbul: Boğaziçi Yayınları, 2012), 29-33.

${ }^{4}$ Andrew B. Newberg, Stephanie K. Newberg, "Dinî ve Manevî Tecrübenin Nöropsikolojisi”, çev. Şeyma Turan, Din ve Maneviyat Psikolojisi, Ed. İhsan Çapçığlu, Ali Ayten (Ankara: Phoenix Yayınevi, 2013), 401; Nevzat Tarhan, İnanç Psikolojisi (İstanbul: Timaş Yayınları, 2014), 22,193.

5 Osman Pazarlı, Din Psikolojisi (İstanbul: Remzi Kitabevi, 1982), 45; Hasan Dam, “Çocukluk Dönemi Din Eğitimi”, Gelişimsel Basamaklarına Göre Din Eğitimi, ed. Mustafa Köylü (Ankara: Nobel Yayınları, 2013), 30.

${ }^{6}$ Ahmed Çelebi, İslam'da Eğitim-Öğretim Tarihi (İstanbul: Damla Yayınevi, 2013), 27; Şakir Gözütok, İlk Dönem İslam Eğitim Tarihi (Ankara: Fecr Yayınları, 2002), 143-154; Mahmut Dündar, İlk Dönem İslami Eğitim-Öğretim Faaliyetleri (İstanbul: İșrak Yayınları, 2011), 30.

7 George Makdisi, Ortaçağ’da Yüksek Öğretim (İstanbul: Klasik Yayınları, 2015), 55; Çelebi, İslam’da Eğitim-Öğretim Tarihi, 29. 
çeşitliliği ile temayüz etmiştir. ${ }^{8}$

Türkiye Cumhuriyeti'nin kurulmasından sonra, din eğitimi veren müstakil kurumlar kapatılarak eğitim ve öğretim Milli Eğitim Bakanlığı (MEB) çatısında toplanırken, ${ }^{9}$ özellikle çocukluğun erken dönemi için din veya değerler eğitimi ile ilgili olarak herhangi bir adım atılmamıştır. Bu eksikliğin tespitine ve ebeveynlerden gelen yoğun talebe binaen, ${ }^{10}$ yaygın din eğitimi kurumlarının bağlı olduğu Diyanet İşleri Başkanlığı (DİB), yaygın din eğitimi için belirlenmiş olan yaș sınırının kaldırılmasından sonra, ${ }^{11}$ Kur'an Kursları bünyesine 4-6 yaş grubu Kur'an kurslarını da ekleyerek bu açığı kapatma yoluna gitmiştir. Bu kurslarda ders verecek öğreticilerin tespiti için 2013'te mülakat yapılmış ve mülakat neticesinde seçilen 87 öğreticiden 80'inin katıldığı bir hizmet içi eğitim semineri düzenlenmiştir. ${ }^{12}$ 4-6 yaş grubu Kur'an kursları, böylece 2013-2014 eğitim-öğretim yılında belirlenen 10 pilot ilde yürürlüğe koyulmuş, ${ }^{13}$ 2014-2015 eğitim-öğretim yılında da tüm Türkiye'de uygulanmaya başlanmıştır. Kurulduğu ilk andan en son veri bilgileri açıklanan 2020 yılına kadar bu kurslara yoğun bir ilginin olduğu dikkatleri çekmektedir. Nitekim 4-6 yaş grubu Kur'an kursları, 2014 yılında 554 kurs, 758 öğretici ve 15.265 öğrenci ${ }^{14}$ ile eğitime başlarken bu sayılar 2020 yılında 5.575 kurs, 10.096 öğretici ve 181.808 öğrenciye ${ }^{15}$ yükselmiştir. 4-6 yaş grubu Kur'an kursları, 48 ayını tamamlayan ve 72 ayını doldurmayan öğrencilere yöneliktir. ${ }^{16} 2018$ yılında yayınlanan öğretim programına göre bu kursların ders içeriğine bakıldığında temel Kur'an bilgisi, değerler eğitimi ve temel dini bilgilerin öne çıtı̆̆ğ görülmektedir. ${ }^{17}$

4-6 yaş grubuna yönelik Kur'an kurslarının etkili ve verimli bir eğitim dinamiği ile varlığını sürdürebilmesi adına paydaşlarına yönelik girişim ve çalışmalarının önemi yadsınamaz. Bu anlamda söz konusu paydaşlardan öğrenci, ${ }^{18}$ veli, ${ }^{19}$

8 Osman Öztürk, "Basic Principles Of Primary Schools Education In Ottoman Empire”, İslam Tetkikleri Enstitüsü Dergisi 4/1-2 (1978), 214; Mefail Hızl, "Osmanlı Döneminde Bir İlköğretim Kurumu Olarak Sıbyan Mektepleri”, İslam Tarihinin Problemleri Kolokyumu (Şanlıurfa: Elif Matbaası, 2008), 119125.

${ }^{9}$ Halis Ayhan, Türkiye'de Din Eğitimi (İstanbul, DEM Yayınları, 2014), 49; Mustafa Öcal, "Cumhuriyet Döneminde Türkiye'de Din Eğitimi ve Öğretimi”, Uludağ Üniversitesi İlahiyat Fakültesi Dergisi, 7 (1998), 242.

10 Diyanet İşleri Başkanlığı (DİB), “Kur'an Kursları Öğretim Programı (4-6 Yaş Grubu)” (Erişim: 1 Ekim 2020).

11 DİB, "Kur'an Kursları Öğretim Programı (4-6 Yaş Grubu)”.

12 Diyanet İşleri Başkanlığı (DİB), “Faaliyet Raporu 2013” (Erişim: 1 Ekim 2020).

13 DİB “Faaliyet Raporu 2013” (Erişim: 1 Ekim 2020).

14 Diyanet İşleri Başkanlığı (DİB), “Faaliyet Raporu 2014” (Erişim: 1 Ekim 2020).

15 Diyanet İşleri Başkanlığı (DİB), “Faaliyet Raporu 2020” (Erişim: 11 Eylül 2021).

16 Diyanet İşleri Başkanlığı (DİB), "Diyanet İşleri Başkanlığı Kur’an Eğitim Ve Öğretimine Yönelik Kurslar Ve Öğrenci Yurt Ve Pansiyonları Yönergesi” (Erişim: 1 Ekim 2020).

17 DİB, "Kur'an Kursları Öğretim Programı (4-6 Yaş Grubu)".

18 Bk. Süleyman Şen, 4-6 Yaş Grubu Çocuklarda Kur’an Tasavvuru (Uşak: Uşak Üniversitesi Sosyal Bilimler Enstitüsü, Yüksek Lisans Tezi, 2018); Tuba Gül, 4-6 Yaş Dönemi Çocuklarda Merhamet Eğitimi (Konya: Necmettin Erbakan Üniversitesi Sosyal Bilimler Enstitüsü, Yüksek Lisans Tezi, 2019); Muhammed Ali Yazıbașı, “Kur’an Kursu Öğreticilerine Göre 4-6 Yaş Kur’an Kursu Öğreticisi, Öğrencisi ve Öğrenci Velisinin İhtiyaç ve Beklentileri (Kırıkkale Örneği)”, Dini Araştırmalar 23/57 (15 Haziran 
öğretim programı ${ }^{20}$ ve öğreticiler ${ }^{21}$ üzerine akademik camiada çalışmalar ele alınmıştır. Bu çalışmanın ana yönelimini oluşturan öğretici perspektifinden konuya bakıldığında, bu kursların açılmasına karar verilmesinin ardından, burada öğretici olarak görev yapacak DİB personelinin ilk olarak mülakatla seçildiği yukarıda ifade edilmişti. Bunun yanı sıra DİB'in 4-6 yaş grubu Kur'an kurslarında görev alan/alacak öğreticilere yönelik çalışmalarını üç alt başlıkta kategorize etmek mümkündür:

A. Yeterlik Geliştirme Toplantıları: 4-6 yaş grubu Kur’an kurslarında görev alan/alacak öğreticilerin hangi meslekî yeterliklere sahip olması gerektiğine ilişkin DİB tarafından toplantılar düzenlediğine dair bilgiler, faaliyet raporlarına yansımıştır. Burada ele alınan konular ve belirlenen yeterlik içeriğine göre hizmet içi eğitim seminerleri düzenlenmekte ve bu yeterlikler, seminerlerde öğreticilere kazandırılmaya çalışılmaktadır. Bunun için raporlara iki toplantı bilgisi yansımıştır. İlk toplantı 9 Mart 2017'de Ankara Rıfat Börekçi Eğitim Merkezi'nde yapılmıștır ve bu toplantıya 25 kiși katılmıştır. Toplantının amacı "4-6 yaş grubu Kur'an kursu öğreticilerinin yeterliklerinin tespit edilmesi ve bu yeterliklerin öğreticilere kazandırılması" olarak belirlenmiştir. ${ }^{22}$ İkinci toplantı ise 12 Aralık 2019'da yapılmıştır. Bu toplantının kapsamı da "öğretici yeterliklerinin geliştirilmesi"dir. ${ }^{23}$

B. Hizmet İçi Eğitim Seminerleri: Öğreticiler için belirlenen yeterlik alan ve içeriklerinden sonra, bu yeterlikleri 4-6 yaş grubu Kur'an kurslarında görev alan/alacak öğreticiye kazandırmak adına pek çok hizmet içi eğitim semineri düzenlenmiştir. Bu anlamda Ağustos 2014'te 166 öğreticiye, ${ }^{24} 2015$ 'te iki dönem ha-

2020).

19 Bk. İbrahim Kurt, Velilerin 4-6 Yaș Kur'an Kurslarından Memnuniyet Düzeyleri ve Beklentileri Üzerine Bir Araștırma (Ankara Örneği) (Çorum: Hitit Üniversitesi Sosyal Bilimler Enstitüsü, Yüksek Lisans Tezi, 2017); Ayşegül Gün, "Veli Ve Öğretici Görüşleri Doğrultusunda 4-6 Yaş Grubu Kur’an Kursu Eğitimi" Amasya Üniversitesi İlahiyat Fakültesi Dergisi, 7 (2016), 44.

${ }^{20}$ Bk. Ali Gücen, Ahmet Çakmak, Mustafa Fatih Ay, "4-6 Yaş Kur'an Kursu Öğretim Programının Öğretici Görüşleri Çerçevesinde Değerlendirilmesi”, Uluslararası Erken Çocukluk Dönemi Kongresi Bildiri Kitabı, Ed. Mücahit Kıbrıs (İstanbul: İstanbul Büyükșehir Belediyesi, 2016); İbrahim Așlamacı, "4-6 Yaş Kur'an Kursu Öğretim Programının (2018) Eğitim Programı Temel Öğeleri Açısından Değerlendirilmesi”, Erken Çocukluk Dönemi Din-Ahlak-Değerler Eğitimi ve Sorunları-1, ed. Mehmet Bayyiğit, Mehmet Özkan, Ahmet Ali Çanakcı, Asem Hamdy A. Abdelghany, (Konya: Palet Yayınları, 2020); M. Zeki Aydın, Esma Budak, "Diyanet İşleri Başkanlığı 2013 ve 2020 Yılları 4-6 Yaş Grubu Kur'an Kursu Öğretim Programlarının Değerler Eğitimi Açısından İncelenmesi ve Öneriler", Erken Çocukluk Dönemi Din-Ahlak-Değerler Eğitimi ve Sorunları-1, ed. Mehmet Bayyiğit, Mehmet Özkan, Ahmet Ali Çanakcı, Asem Hamdy A. Abdelghany, (Konya: Palet Yayınları, 2020).

21 Bk. Kevser Tüfekçi, Diyanet İșleri Başkanlığı 4-6 Yaş Kur'an Kursları Eğitiminin Öğretici ve Veli Görüşlerine Göre İncelenmesi (Gaziantep: Gaziantep Üniversitesi Eğitim Bilimleri Enstitüsü, Yüksek Lisans Tezi, 2020); Zülfi Doğan, 4-6 Yaș Grubu Kur’an Kursu Öğreticilerinin Eğitim-Öğretim Yeterlik Algıları (Kayseri Örneği) (Kayseri: Erciyes Üniversitesi, Yüksek Lisans Tezi, 2019); Muzaffer Üzümcü, “4-6 Yaş Grubu Kur’an Kursu Öğretici Yeterlikleri: Öğretmenlik Mesleği Genel Yeterlikleriyle Karşılaştırmalı Bir Değerlendirme", Erken Çocukluk Dönemi Din-Ahlak-Değerler Eğitimi ve Sorunları-1, ed. Mehmet Bayyiğit, Mehmet Özkan, Ahmet Ali Çanakcı, Asem Hamdy A. Abdelghany, (Konya: Palet Yayınları, 2020).

22 Diyanet İşleri Başkanlı̆̆ (DỉB), “Faaliyet Raporu 2017” (Erişim: 5 Ekim 2020).

${ }^{23}$ Diyanet İşleri Başkanlığı (Dỉ), “Faaliyet Raporu 2019” (Erişim: 5 Ekim 2020).

${ }^{24}$ DİB, "Faaliyet Raporu 2014". 
linde 5 gün süreli olmak üzere Rize ve Afyonkarahisar'da 444 öğreticiye, ${ }^{25}$ Temmuz 2017'de 29 Mayıs Üniversitesi'nde 38 öğreticiye, ${ }^{26}$ Ocak ve Kasım/Aralık 2018 'de ilkinde 275, diğerinde ise 234 öğreticiye ${ }^{27}$, Ocak 2019'da iki dönem halinde 1.232 öğreticiye ${ }^{28}$ ve 18-24 Ocak 2020 ile 26 Ocak- 1 Şubat 2020 tarihleri arasında 1.169 öğreticiye ${ }^{29}$ hizmet içi eğitim semineri verilmiştir.

C. İlgili Kurumlarla İş birliği: 4-6 yaș grubu Kur'an kurslarının hem eğitim, hem psikoloji hem ilahiyat hem de çocuk gelişimi gibi alanlarla yakın irtibatlı olması, DİB’in ilgili biriminin interdisipliner bir anlayışla, ilgili tüm paydaş kurum ve kuruluşlarla işbirliği yapmasını gerektirmektedir. Bu anlamda, bugüne kadar Başkanlığın iki girişimde bulunduğu tespit edilmiştir. Birincisi, 2014 yılında bu kurumlarda görev alacak öğreticilerin çocuk gelişimi ve faaliyetleri ile alakalı formasyon sahibi olmaları için MEB Hayat Boyu Öğrenme Genel Müdürlüğü ile işbirliği içerisinde 4-6 yaş çocuk eğitimi ve etkinlikleri modülü programı hazırlanması ve bu programın aynı yıl uygulamaya konulmasıdır. ${ }^{30}$ İkincisi ise, Marmara Üniversitesi rektörlügüne yazılan bir yazıda 2018 yılında İlahiyat fakültesi öğrencilerine yönelik Okul Öncesi Eğitimi Anabilim Dalı ile Çocuk Gelişimi Anabilim Dalı Çift Anadal Programı ve Yandal Programı alanlarında kontenjanların artırılması, Eğitim Fakültesi Okul Öncesi Eğitimi Anabilim Dalı ile Çocuk Gelişimi Anabilim Dalı öğrencilerine İlahiyat Fakültelerinde Çift Anadal ve Yan Anadal programları alanlarında kontenjan imkânı tanınması, Din Eğitimi Anabilim Dalı müfredatında erken çocukluk dönemi din eğitimi konularına yer verilmesi hususlarının değerlendirilmesinin istenmesidir. ${ }^{31}$ Bunlarla birlikte erken çocukluk dönemine ilişkin lisansüstü eğitim faaliyetleri de önerilmektedir. ${ }^{32}$

Öte yandan 4-6 yaş grubu Kur'an kurslarında görev alan/alacak öğreticiler ile ilgili çeşitli araștırmalar da yapılmıștır. Bu kurumlarda görev yapan öğreticilerin gerek kendileri ile alakalı olan meslekî ve alan bilgisi yeterlikleri gerekse doğrudan bu kurumların eğitim açısından geleceğini de ilgilendiren beklenti ve görüşlerinin tespiti önem arz etmiş ve alan araştırmacılarının çalışma yönelimlerinden biri olmuştur. $\mathrm{Bu}$ anlamda çalıșmanın temel amacı; 4-6 yaş grubu Kur'an kursları ile ilgili hem öğreticiyi hem de diğer paydaşların yanı sıra öğreticiyi de konu alan hem nitel hem de niteli de barındıran karma desenli araştırmaları tespit edip, kurslarla ilgili öğretici görüşlerinin genel bir fotoğrafını ortaya koymaktır. Bu temel amaç çerçevesinde 4-6 yaş grubu Kur'an kurslarının program süreçlerini betimlemek ve eğitimin kazanımlarının önündeki sorunları ortaya çıkarmak ise araştır-

25 Diyanet İşleri Başkanlığı (DİB), “Faaliyet Raporu 2015” (Erișim: 5 Ekim 2020).

26 Dİ, "Faaliyet Raporu 2017".

27 Diyanet İşleri Başkanlığı (DİB), “Faaliyet Raporu 2018” (Erişim: 5 Ekim 2020).

28 Dİ, "Faaliyet Raporu 2014".

29 Dİ, "Faaliyet Raporu 2020".

30 DİB, "Faaliyet Raporu 2014".

31 DİB, "Faaliyet Raporu 2018".

32 İsmail Sağlam, “Kur'an Kursları 4-6 Yaș Din Eğitimi Projesi Hikâyesi ve Mevcut Durum”, Erken Çocukluk Dönemi Din-Ahlak-Değerler Eğitimi ve Sorunları-2, ed. Mehmet Bayyiğit, Mehmet Özkan, Ahmet Ali Çanakcı, Asem Hamdy A. Abdelghany, (Konya: Palet Yayınları, 2020), 2 
manın alt amaçlarıdır. Çalışmayı önemli kılan iki nedenden söz edilebilir. Birincisi; kurslarla ilgili genel bir değerlendirme yapmaya imkân tanıması, ikinci ise Başkanlıktaki eğitim programcılarına bir projeksiyon tutma potansiyelini barındırmasıdır.

\section{Yöntem}

4-6 yaş grubu Kur’an kursları ile alakalı öğreticiyi merkeze alan araştırmaları değerlendirmeyi amaçlayan bu çalışma kapsamında söz konusu çalışmalar incelendiğinde, bunların büyük bir kısmının nitel çalışmalar olduğu görülmektedir. Bilimsel araştırma literatürü incelendiğinde, nitel desenli çalışmaları ele alıp mevcut durumu resmeden çalışmalar için uygun yöntemin meta-sentez yöntemi olduğu düşünülmektedir. Dolayısıyla bu çalışmada da meta-sentez yöntemi kullanılmıştir.

Meta-sentez, belirlenen bir araştırma problemi ile doğrudan ya da dolaylı olarak bağlantılı olan nitel çalışmaları tespit edip bu çalışmalardan elde edilen bulguları veri olarak kullanarak ilgili çalışmalara dair bir sonuca ulaşan niteliksel bir araștırma türüdür.33 Bir konu ile ilgili yapılan nitel araștırmaların nihai olarak ne demek istediğini, o konuya dair neyi tamamlayıp neyi eksik bıraktığını tespit etmek adına meta-sentezin ideal bir araştırma yöntemi olduğu söylenebilir. Bir konu ile ilgili hangi bilimsel çalışmaların yapıldığı, söz konusu çalışmaların alanda hangi boşlukları doldurduğu ile ilgili soruların cevaplanmasında ve alandaki eksikliklerin tespit edilerek bu eksiklikleri ortaya koyacak bilimsel araştırmalar yapılmasında meta-sentez yöntemi işlevsel bir özelliğe sahiptir. Böylece artan, büyüyen ve çeşitlenen bir araştırma alanında ulaşılan nokta tespit edilebilir. Meta-sentez, uzun süre sağlık alanındaki araştırmalar için kullanılan, hatta gelecekte de bu alana pek çok çalışma kazandıracağına inanılan bir araştırma yöntemi olup ${ }^{34}$ daha sonra eğitim bilimleri araştırmalarının da dikkatini çekmiş, bu alandaki araştırmalarda kullanılmıștır. ${ }^{35} \mathrm{Bu}$ yöntem eğitim bilimlerindeki araştırmalarda ilk olarak "Metaetnografi" 36 ismi ile kullanılmış ise de, farklı çalışmalarda "anlatı sentezi, metayorumlama, tematik içerik analizi" gibi isimlerine de rastlanılabilmektedir. ${ }^{37}$ Metasentez yöntemi, böylece bir içerik analizi türüdür ve nitel ve karma çalışmalar için

33 Lela Zimmer, "Qualitative Meta-Synthesis: A Question Of Dialoguing With Nexts”, Journal Of Advanced Nursing 53/3 (2006), 312.

${ }^{34}$ Denish Walsh, Soo Downe, "Meta-Synthesis Method For Qualitative Research: A Literature Review", Journal Of Advanced Nursing 50/2 (2005), 210; Terese Bondas, Elisabeth O. C. Hall, "Challenges İn Approaching Metasyntesis Research", Qualitative Health Research 17/1 (2007), 119; Serkan Dinçer, "Content Analysis In For Educational Science Research: Meta Analysis, Meta-Synthesis, And Descriptive Content Analysis", Bartın University Journal Of Faculty Of Education 7/1 (Ocak 2018), 180.

35 Seyat Polat, Osman Ay, "Meta-Sentez: Kavramsal Bir Çözümleme”, Eğitimde Nitel Araştırmalar Dergisi 4/1 (2016), 52; Bondas, Hall, “Challenges In Approaching Metasynthesis Research”, 119; Dinçer, “Content Analysis In For Educational”, 180.

36 George W. Noblit, "Meta-Etnography: Adoptation And Return”, Cultural Constructions Of Identity, ed. Luis Urrieta, George W. Noblit (New York: Oxford University Press, 2018), 40-45.

37 R. Campbell, P. Pound, M. Morgan, G. Daker-White, N. Britten, R. Pill, L. Yardley, C. Pope, J. Denovan, "Evaluating Meta-Ethnography Systematic Analysis And Synthesis Of Qualitative Research", Helath Technology Assesment 15/43 (2011), 6; Muammer Çalık, Mustafa Sözbilir, "Parameters Of Content Analysis", Education And Science 39/174 (2014), 34. 
işlevseldir. Nicel çalışmalar için daha çok meta-analiz yöntemi tercih edilmektedir. ${ }^{38}$

Meta-sentez yönteminin kullanıldığı bir çalışmada takip edilecek adımlara dair açıklamalar bulunmaktadır. Bu çalışmada takip edilen işlem adımları, Polat ve Ay'ın farklı kaynaklardan yararlanarak ortaya attıkları işlem adımları ile benzerdir: Öncelikle araştırma problemi ve bu problem çerçevesinde alt sorular belirlenir. Bu sorular çerçevesinde alanyazın taramaya tabi tutulur. Problem ve amaç çerçevesinde işleme dâhil edilecek çalışmalar için ölçüt belirlenir. Dâhil edilen çalışmalar okunur, temalar belirlenir ve sentezleme işlemi yapılır. Son olarak da bulgular ortaya konur ve araştırma raporlandırılarak tamamlanır. Bütün bu işlem adımları, sırasıyla aşağıdaki Şekil 1'de gösterilmiştir: ${ }^{39}$

Şekil 1: Araştırmanın Așamaları

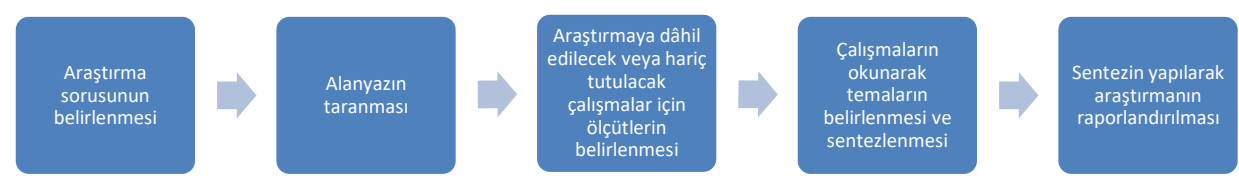

Meta-sentez yönteminin kullanıldığı bir çalışmada geçerlik ve güvenirliği artıracak kurallar şu şekilde ifade edilebilir: 40

1. Çalışmanın amacının ve probleminin açık bir şekilde ortaya konulması.

2. Çalışmanın benzer çalışmalardan farkının açıkça ortaya konulması.

3. Araştırma kapsamına alınacak ve bu kapsamın dışında bırakılacak çalışmalar ile ilgili ölçütlerin açık bir şekilde belirtilmesi.

4. Alanyazın taranırken ulaşılan çalışmaların sayısı ve bu çalışmalardan senteze dâhil edilenlerin detaylı bir şekilde açıklanması.

5. Çalışma grubuna dâhil edilen çalışmaların evreni, örneklemi, gerçekleştiği coğrafya, veri toplama tekniği, veri çözümleme yöntemleri de belirlenmesi ve imkân dâhilinde bunların bir tablo ile sunulması.

6. Verilerin çözümlenmesi ve temaların oluşturulmasının ayrıntılı bir şekilde açıklanması.

7. Temaların belirlenmesinin birden çok uzman tarafından yapılması ve kodlayıcılar arasındaki tutarlılığın sağlanması.

8. Sentez işlemi için yeterli sürenin ayrılması ve bu sürenin açıklanması.

9. İmkân dâhilinde, incelemeye tabi tutulan çalışmalardan kesit veya pasajların da verilmesi.

10. Sentezleme ve raporlama aşamasında geniş bir yorumlama yelpazesine

38 Çalık, Sözbilir, "Parameters Of Content Analysis", 34; Polat, Ay, "Meta-Sentez “, 54; Dinçer, "Content Analysis İn For Educational Science Research", 180.

39 Polat, Ay, "Meta-Sentez", 56.

40 Zimmer, "Qualitative Meta-Synthesis”, 317; Çalık, Sözbilir, “Parameters Of Content Analysis”, 34- 35; Polat, Ay, "Meta-Sentez", 57- 58. 
önem verilmesi.

11. Sonuçların araştırmacılar, uygulayıcılar ve politikacılar için açık ve net bir şekilde ortaya konulması.

Yukarıda sıralanan kurallara araştırmacılar uymaya özen göstermiştir.

\section{1. Ölçütler}

4-6 yaş grubu Kur'an kursları ile ilgili öğretici görüşlerini ele alan çalışmalar ile ilgili oluşturulacak çalışma grubunda, yöntem de göz önünde bulundurularak belirlenen ölçütler şunlardır:

> Çalışmaların 4-6 yaş grubu Kur'an kursları ile ilgili olması.

$>$ Çalışmaların öğretici görüşlerine dayanması.

$>$ Çalışmaların nitel desende olması. Bu anlamda karma desenle oluşturulmuş çalışmaların nitel bulguları da araştırma kapsamına alınmiştır.

Ayrıca araştırmacıların konuya ilişkin ele aldıkları ilk ve kapsamlı çalışmaları ölçütlere dâhil edilmiş, bu çalışmalardan türetilen diğer çalışmalar araştırma grubuna dâhil edilmemiştir. Mesela bir çalışmanın tezi ve makalesi varsa tezi incelenmiş, makale dikkate alınmamıştır.

\subsection{Calıșma Grubu}

Problem, amaç, yöntem ve ölçütler çerçevesinde alanyazın taranmış ve 9 yüksek lisans tezi, 1 kitap, 10 makale ve 4 bildiri olmak üzere 24 araștırmadan oluşan bir çalışma grubu oluşturulmuştur. Çalışma grubu ile ilgili bilgiler Tablo 1'de gösterilmiştir. Günümüze kadar konu ile ilgili öğretici görüşlerini ele alan 9 yüksek lisans tezi, bir kitap, 10 makale ve 4 adet tebliğe ulaşılmıştır.

Tablo 1. Çalıșma Grubundaki Araștırmalar

\begin{tabular}{|l|l|l|l|}
\hline Araştırmacı & Araştırmanın başlı̆̆ı & $\begin{array}{l}\text { Araştırma } \\
\text { türü }\end{array}$ & $\begin{array}{l}\text { Araştırmanın } \\
\text { yöntemi }\end{array}$ \\
\hline Betül Yıldırım & $\begin{array}{l}\text { Okul Öncesi Eğitim Kurumlarına Devam Eden 4-6 } \\
\text { Yaş Arası Çocuklara Din Eğitimi (Sivas İli Örneği) }\end{array}$ & $\begin{array}{l}\text { Yüksek Lisans } \\
\text { Tezi }\end{array}$ & Nitel \\
\hline Samet Yağcı & $\begin{array}{l}\text { Öğreticilere Göre DïB 4-6 Yaş Grubu Kur'an Kurs- } \\
\text { ları (İzmir İli Örneği) }\end{array}$ & $\begin{array}{l}\text { Yüksek Lisans } \\
\text { Tezi }\end{array}$ & Nitel \\
\hline Zülfi Doğan & $\begin{array}{l}\text { 4-6 Yaş Kur'an Kursu Öğreticilerinin Eğitim- } \\
\text { Öğretim Yeterlik Algıları (Kayseri Örneği) }\end{array}$ & $\begin{array}{l}\text { Yüksek Lisans } \\
\text { Tezi }\end{array}$ & Karma \\
\hline Bekir Sarı & $\begin{array}{l}\text { Kur'an Kursları Öğretici Kitabındaki Uygulamala- } \\
\text { rın İncelenmesi }\end{array}$ & $\begin{array}{l}\text { Yüksek Lisans } \\
\text { Tezi }\end{array}$ & Karma \\
\hline Elif Acur & $\begin{array}{l}\text { Öğretici Görüşleri Bağlamında Dỉ 4-6 Yaş } \\
\text { Kur'an Kurslarındaki Değerler Ĕgitimi Uygulama- } \\
\text { larının Değerlendirilmesi }\end{array}$ & $\begin{array}{l}\text { Yüksek Lisans } \\
\text { Tezi }\end{array}$ & Nitel \\
\hline
\end{tabular}




\begin{tabular}{|c|c|c|c|}
\hline Büşra Kara & $\begin{array}{l}\text { Okul öncesi Dönemi (4-6 Yaş Grubu) Eğitiminde } \\
\text { Görev Alan Eğitimcilerin/Din Görevlilerinin Pe- } \\
\text { dagojik Yeterlilikleri }\end{array}$ & $\begin{array}{l}\text { Yüksek Lisans } \\
\text { Tezi }\end{array}$ & Nitel \\
\hline Hatice Bayka & $\begin{array}{l}\text { Öğretici ve Veli Görüşleri Açısından Kur'an Kurs- } \\
\text { ları Ögretim Programı (4-6 Yaş Grubu)'nın De- } \\
\text { ğerlendirilmesi }\end{array}$ & $\begin{array}{l}\text { Yüksek Lisans } \\
\text { Tezi }\end{array}$ & Nitel \\
\hline Kevser Tüfekçi & $\begin{array}{l}\text { DİB 4-6 Yaş Kur'an Kursları Eğitiminin Öğretici } \\
\text { ve Veli Görüşlerine Göre İncelenmesi }\end{array}$ & $\begin{array}{l}\text { Yüksek Lisans } \\
\text { Tezi }\end{array}$ & Nitel \\
\hline $\begin{array}{l}\text { Ayșe Sevde } \\
\text { Karaca }\end{array}$ & $\begin{array}{l}\text { DíB 4-6 Yaş Kur’an Kursu Öğgrencilerine Uygula- } \\
\text { nan Değerler Eğitiminin Öğretici Görüşleri Açı- } \\
\text { sindan İncelenmesi }\end{array}$ & $\begin{array}{l}\text { Yüksek Lisans } \\
\text { Tezi }\end{array}$ & Nitel \\
\hline $\begin{array}{l}\text { Mehmet } \\
\text { Korkmaz }\end{array}$ & $\begin{array}{l}\text { 4-6 Yaş Grubu Kur'an Kurslarında Din Eğitimi } \\
\text { (Sorunlar ve Çözüm Önerileri) }\end{array}$ & Kitap & Karma \\
\hline $\begin{array}{l}\text { Mehmet } \\
\text { Korkmaz }\end{array}$ & $\begin{array}{l}\text { 4-6 Yaş Grubu Kur'an Kursu Öğreticilerinin Ĕ̆i- } \\
\text { tim-Öğretim Yeterlikleri Üzerine Bir Araştırma }\end{array}$ & Makale & Karma \\
\hline $\begin{array}{l}\text { Muzaffer } \\
\text { Üzümcü/ } \\
\text { Nuran Çınar }\end{array}$ & $\begin{array}{l}\text { Öğreticilerine Göre Diyanet 4-6 Yaş Kur’an Kurs- } \\
\text { ları }\end{array}$ & Makale & Nitel \\
\hline M. Fatih Genç & $\begin{array}{l}\text { Diyanet İşleri Başkanlı̆̆ı'na Bağlı 4-6 Yaş Grubu } \\
\text { Kur'an Kurslarında Din Eğitimi }\end{array}$ & Makale & Nitel \\
\hline $\begin{array}{l}\text { Muhammed Ali } \\
\text { Yazıbaşı }\end{array}$ & $\begin{array}{l}\text { Kur'an Kursu Öğreticilerine Göre 4-6 Yaş Kur'an } \\
\text { Kursu Öğreticisi, Öğrencisi ve Öğrenci Velisinin } \\
\text { İhtiyaç ve Beklentileri }\end{array}$ & Makale & Nitel \\
\hline Salih Aybey & $\begin{array}{l}\text { 4-6 yaş Kur'an Kurslarının Eğitim-Öğgretim Faali- } \\
\text { yetleri ve Problemleri (Zonguldak ili Örneği) }\end{array}$ & Makale & Karma \\
\hline Teceli Karasu & $\begin{array}{l}\text { Kur'an Kursu Öğreticilerine Göre Okul Öncesi } \\
\text { Dönemde Din Eğitimi: Muş Örneği }\end{array}$ & Makale & Nitel \\
\hline Ayșegül Gün & $\begin{array}{l}\text { Veli ve Öğretici Görüşleri Doğrultusunda 4-6 Yaş } \\
\text { Grubu Kur'an Kursu Eğitimi: Samsun ili Örneği }\end{array}$ & Makale & Karma \\
\hline Zeynep Yüksel & $\begin{array}{l}\text { 4-6 Yaş Kur'an Kursu Öğreticilerinin Öğretim } \\
\text { Yöntemleri Açısından Yeterlik Algıları (Çankırı } \\
\text { Örneği) }\end{array}$ & Makale & Karma \\
\hline Ramazan Diler & $\begin{array}{l}\text { 4-6 Yaş Kur’an Kursu Öğreticilerine Göre Mah- } \\
\text { remiyet Eğitimi ve Önemi (Nitel Bir Analiz) }\end{array}$ & Makale & Nitel \\
\hline İbrahim Kurt & $\begin{array}{l}\text { Salgın Döneminde 4-6 Yaş Grubu Kur'an Kursları } \\
\text { (Ankara Örneği) }\end{array}$ & Makale & Nitel \\
\hline
\end{tabular}




\begin{tabular}{|l|l|l|l|}
\hline $\begin{array}{l}\text { Ali Gücen } \\
\text { Ahmet Çakmak } \\
\text { M. Fatih AY }\end{array}$ & $\begin{array}{l}\text { 4-6 Yaş Kuran Kursu Öğretim Programını Öğre- } \\
\text { tici Görüşleri Çerçevesinde Değerlendirilmesi }\end{array}$ & Bildiri & Nitel \\
\hline $\begin{array}{l}\text { Önder Arpacı } \\
\text { Fatma } \\
\text { Soydemir }\end{array}$ & $\begin{array}{l}\text { DỉB'in 4-6 Yaş Kur'an Kurslarında Din-Ahlak- } \\
\text { Değerler Eğtimi Uygulamaları ve Sorunları } \\
\text { (Edirne Uygulama Örneği) }\end{array}$ & Bildiri & Nitel \\
\hline Zehra Gelici & $\begin{array}{l}\text { DïB 4-6 Yaş Kur'an Kursları, Sorunlar ve Çözüm } \\
\text { Önerileri (İstanbul, Üsküdar Örneği) }\end{array}$ & Bildiri & Nitel \\
\hline Hatice Ayar & $\begin{array}{l}\text { 4-6 Yaş Grubu Kur'an Kurslarında Elifbâ Öğreti- } \\
\text { mi: Uygulamalar ve Zorlanma Alanları }\end{array}$ & Bildiri & Nitel \\
\hline
\end{tabular}

\subsection{Veri Analizi}

30 Eylül 2021 tarihine kadar yayınlanmıș tebliğ, makale ve kitaplar ile Yüksek Öğretim Kurulu Ulusal Tez Merkezi'ne yüklenmiş tezler taranmıştır. Taramada 4-6 yaş Kur'an kursu kavram kümesi anahtar kavram olarak belirlenmişir. Ölçütler çerçevesinde belirlenen araştırmalar NVIVO programına yüklenmiştir. Yalnızca kitap çalışması programa yüklenmemiştir. Her bir araştırmanın bulgu ve sonuçlar iki araştırmacı tarafından da okunmuş ve kodlamalar yapılmıştır. Bu adımda çalışma grubundaki araştırmaların alıntıladığı deşifre metinler okunarak kodlama yapılmıştır. Kimi araștırmaların kodları bu araștırmada da bir kod olarak belirlenmiştir. Ancak bu çalışmada alıntılara yer verilmemiş sadece ilgili araştırmanın sayfasına atıf verilmiştir. Sonrasında kodlamalar karşılaştırılmış ve araştırmacılar metinleri tekrar tekrar okumuş kodlarda değişiklikler ve düzenlemeler yapmıştır. Sonraki adımda kodların hangi temalar altında işleneceği belirlenmiş ve araştıramanın sonuçları raporlandırılmıștır.

Tablo 2: Belirlenen temalar ve kısa açıklamaları

\begin{tabular}{|l|l|l|}
\hline Temalar & Alt temalar & Açılama \\
\hline $\begin{array}{l}\text { Program } \\
\text { geliştirme } \\
\text { süreci }\end{array}$ & Amaç & $\begin{array}{l}\text { Kursun amaçlarına yönelik görüşme metin- } \\
\text { lerini kapsar. }\end{array}$ \\
\cline { 2 - 3 } & İçerik & $\begin{array}{l}\text { Kurs programının içeriğine yönelik görüşme } \\
\text { metinlerini kapsar. }\end{array}$ \\
\cline { 2 - 3 } & $\begin{array}{l}\text { Eğitim durumları (öğretme- } \\
\text { ŏğrenme süreci) }\end{array}$ & $\begin{array}{l}\text { Yöntem, materyal kullanımı, sınıf yönetimi, } \\
\text { özel eğitim konularına yönelik görüşme me- } \\
\text { tinlerini kapsar. }\end{array}$ \\
\cline { 2 - 3 } & Ölçme-değerlendirme & $\begin{array}{l}\text { Kurs programın hedeflerine ne kadar ulaşıl- } \\
\text { dığını belirlemek için gerçekleştirilen etkin- } \\
\text { liklere yönelik görüşme metinlerini kapsar. }\end{array}$ \\
\hline $\begin{array}{l}\text { Yapısal } \\
\text { sorunlar }\end{array}$ & Yaştan kaynaklı & $\begin{array}{l}\text { Öğrencilerin yaşlarına ve sınıflamanın yaşla- } \\
\text { ra göre yapılmasına yönelik görüşme metin- } \\
\text { lerini kapsar. }\end{array}$ \\
\hline
\end{tabular}




\begin{tabular}{|l|l|l|}
\hline Paydaşlardan kaynaklı & $\begin{array}{l}\text { Veli ve çalıșma arkadaşları ile ilgili görüşme } \\
\text { metinlerini kapsar. }\end{array}$ \\
\cline { 2 - 3 } & İdareden kaynaklı & $\begin{array}{l}\text { Diyanet İşleri Başkanlığı'nın kursa yönelik } \\
\text { politikaları ve müftülüklerin kursa yaklaşımı } \\
\text { ile ilgili görüşme metinlerini kapsar. }\end{array}$ \\
\cline { 2 - 4 } & Fiziksel yapıdan kaynaklı & $\begin{array}{l}\text { Fiziksel imkanlara yönelik görüşme metinle- } \\
\text { rini kapsar. }\end{array}$ \\
\hline
\end{tabular}

\section{Bulgular}

Çalıșma grubuna dâhil edilen araștırmaların incelenmesinden sonra listelenen kodlar konulara göre sınıflandırılmıştır. Bu sınıflandırmadan sonra elde edilen kodlardan, 4-6 yaş Kur’an kurslarında görev yapan öğreticilerin, bu kurslar ile ilgili görüşlerinden iki ana tema ortaya çıkarılmıştır.

\subsection{Program Geliștirme Öğeleri}

Öğreticilerin kurslara ilişkin görüşleri, bir bütünlük ve sistem içerisinde toparlandığında, bu görüşlerin program geliştirmenin dört temel öğesi olan amaç, içerik, eğitim durumları ve ölçme-değerlendirme çerçevesinde analiz edilebilir.

\subsubsection{Amaç}

Yapılan araştırmalarda program geliştirme öğelerinden amaç ile ilgili öne çıkan öğretici görüşleri, bu öğreticilerin öğretim programından ve amaçlarından yeteri oranda haberdar olmadıklarını ortaya koymaktadır. Çalışma grubundaki araştırmalarından bazıları öğreticilerin amaçların yeterli, ulaşılabilir ve ihtiyacı karşllar nitelikte olduğu yönünde görüş bildirdiklerini öne sürse de, ${ }^{41}$ pek çoğunda, öğreticilerin öğretim programını yeteri kadar incelemedikleri ve bu programın kendilerine yüklediği amaçların gerektiği ölçüde farkında olmadıkları bulgusu öne çıkmaktadır. ${ }^{2}$ Yağcı'nın araştırmasında öne çıkan “öğreticilerin bir kısmının öğretim programı ile ders programını birbirine karıştırdığı” tespiti, ${ }^{43}$ bu anlamda önemlidir. Araştırmalarda aynı zamanda öğreticilerin neyi öğretmeyi amaçladıklarına dair genel bir bilgiye sahip oldukları görülmektedir. Mesela Bayka'nın çalışmasında, bazı öğreticilerin yegâne amaçlarının Kur'an okumayı öğretmek olmadığı,

41 Samet Yağcı, Öğreticilere Göre Diyanet İşleri Başkanlığı 4-6 Yaş Grubu Kur'an Kursları (İzmir İli Örneği) (İzmir: İzmir Katip Çelebi Üniversitesi, Yüksek Lisans Tezi, 2018), 141; Ayşe Sevde Karaca, DİB 4-6 Yaş Kur'an Kursu Öğrencilerine Uygulanan Değerler Eğitiminin Öğretici Görüşleri Açısından İncelenmesi, (Konya: Necmettin Erbakan Üniversitesi, Yüksek Lisans Tezi, 2020), 82; Önder Arpacı, Fatma Soydemir, “DİB’in 4-6 Yaş Grubu Kur’an Kurslarında Din-Ahlak-Değerler Eğitimi Uygulamaları ve Sorunları: Edirne Uygulama Örneği”, Erken Çocukluk Dönemi Din-Ahlak-Değerler Eğitimi ve Sorunları-2, ed. Mehmet Bayyiğit, Mehmet Özkan, Ahmet Ali Çanakcl, Asem Hamdy A. Abdelghany, (Konya: Palet Yayınları, 2020), 123.

42 Teceli Karasu, "Kur’an Kursu Öğreticilerine Göre Okul Öncesi Dönemde Din Eğitimi: Muş İli Örneği”, İlahiyat Tetkikleri Dergisi 51 (30 Haziran 2019), 479-500; Yağcl, Öğreticilere Göre Diyanet İşleri Başkanlı̆̆ı 4-6 Yaş Grubu Kur'an Kursları,117 ; Doğan, 4-6 Yaş Grubu Kur’an Kursu Öğreticilerinin Eğitim-Öğretim Yeterlik Algıları (Kayseri Örneği), 48.

${ }^{43}$ Yağcl, Öğreticilere Göre Diyanet İşleri Başkanlı̆̆ı 4-6 Yaş Grubu, 80. 
bazı temel dini bilgiler ve değerler eğitimine de işaret etmeleri ${ }^{44}$ programa karşı farkındalığın göstergesi olarak değerlendirilebilir.

\subsection{2. Íçerik}

Araştırmalarda katılımcıların içeriğe ilişkin çeşitli görüşlerine de işaret edilmiştir. Bu görüşler arasında; yaş aralığına verilen derslerin içeriğinde bulunan hem Arapça dilinden kaynaklı bilinmeyen, anlaşılması zor ${ }^{45}$ hem de Allah, melek, ölüm gibi soyut kavram, isim ve terimlerin fazlaca yer aldığına vurgu yapılmaktadır. ${ }^{46}$ Ayrıca, yukarıdaki görüşleri destekler nitelikte bazı çalışmalarda da, içeriğin çocukların gelişimsel seviyelerine uygun olmadığına yönelik görüşlere de yer verilmektedir. ${ }^{47}$ Ancak programın öğrenci seviyesine uygun olduğuna öğretici görüşleri elde eden çalışma da mevcuttur. ${ }^{48}$ Bununla beraber öğreticiler, ahlâk ve değerler eğitimi ile ilgili içeriği önemsemekte, bu kapsamda mahremiyet eğitimi gibi konuların içerikte yer alması gerektiğini de savunmaktadır. ${ }^{49} \mathrm{Bu}$ kursların programında ahlâkî gelişimin de amaçlandığı tespitinden hareketle ${ }^{50}$ öğreticilerin bu taleplerinin dikkate alınabileceği görülmektedir.

İçeriğe dair öne çıkan öğretici görüşleri kodlarından biri de, müfredatın çok yoğun olduğunun görülmesidir. Buna göre öğreticilerin müfredat içeriğini yetiştirmek için yeterli zamana sahip olmadıkları yönündeki ifadeleri çalışmalara yansımıștır.51 Müfredat, bu yönüyle eleștirilmektedir. Tosun'a göre okul öncesi çağda eğitimde akademik ve bilişsel ağırlıklı, konu odaklı bir içerik, bu yaş aralığındaki çocukların hazırbulunuşluk seviyesine uygun değildir. ${ }^{52}$

44 Hatice Bayka, Öğretici Ve Veli Görüşleri Açısından Kur'an Kursları Öğretim Programı (4-6 Yaș Grubu)'nın Değerlendirilmesi (Samsun: Ondokuz Mayıs Üniversitesi, Yüksek Lisans Tezi, 2019), 3334.

45 Muhammet Fatih Genç, “Diyanet İşleri Başkanlığı'na Bağlı 4-6 Yaş Grubu Kuran Kurslarında Din Eğitimi”, İhya Uluslararası İslam Araştırmaları Dergisi 5/2 (24 Temmuz 2019), 506-521; Doğan, 4-6 Yaş Grubu Kur’an Kursu Öğreticilerinin Eğitim-Öğretim Yeterlik Algıları (Kayseri Örneği), 83.

46 Yazıbașı, "Kur’an Kursu Öğreticilerine Göre 4-6 Yaş Kur'an Kursu Öğreticisi, Öğrencisi Ve Öğrenci Velisinin İhtiyaç Ve Beklentileri", 95-116; Elif Acur, Öğretici Görüşleri Bağlamında Diyanet İşleri Başkanlığı 4-6 Yaș Kur'an Kurslarındaki Değerler Eğitimi Uygulamalarının Değerlendirilmesi (Sakarya: Sakarya Üniversitesi, Yüksek Lisans Tezi, 2019), 96.

47 Mehmet Korkmaz, 4-6 yaș Grubu Kur'an Kurslarında Din Eğitimi (Kayseri: Kimlik Yayınları 2019), 65; Büşra Kara, Okul Öncesi Dönemi (4-6 Yaş Grubu) Çocukların Din Eğitiminde Görev Alan Eğitimcilerin/Din Görevlilerinin Pedagojik Yeterlilikleri (Bursa: Uludağ Üniversitesi, Yüksek Lisans Tezi, 2019), 117-118; Bekir Sarı, Kur’an Kursları Öğretici Kitabındaki Uygulamaların İncelenmesi (Erzurum: Atatürk Üniversitesi, Yüksek Lisans Tezi, 2019), 71; Kevser Tüfekçi, Diyanet İşleri Başkanlığı 4-6 Yaş Kuran Kursları Eğitiminin Öğretici ve Veli Görüşlerine Göre İncelenmesi (Gaziantep: Gaziantep Üniversitesi, Yüksek Lisans Tezi, 2020), 58.

48 Arpacl, Soydemir, “DİB'in 4-6 Yaş Grubu Kur'an Kurslarında Din-Ahlak-Değerler Eğitimi Uygulamaları ve Sorunları: Edirne Uygulama Örneği”, 124.

49 Ramazan Diler, “4-6 Yaş Kur’an Kursu Öğreticilerine Göre Mahremiyet Eğitimi ve Önemi (Nitel Bir Analiz)", Eskiyeni, 41 (2020), 639-640.

50 İbrahim Așlamacı, "4-6 Yaş Kur’an Kursu Öğretim Programının (2018) Eğitim Programı Temel Öğeleri Açısından Değerlendirilmesi”, 143.

${ }^{51}$ Karasu, "Kur’an Kursu Öğreticilerine Göre Okul Öncesi Dönemde Din Eğitimi”; Bayka, Öğretici Ve Veli Görüşleri Açısından Kur’an Kursları Öğretim Programı (4-6 Yaş Grubu)’nın Değerlendirilmesi, 37.

52 Cemal Tosun, “Okulöncesi Din Eğitiminin Psikolojik Temellerinin Önemi: 4-6 Yaş Din Eğitimine 
Ayrıca bir çalışmada öğreticilerin kurs programı ile MEB okul öncesi programının içeriğini karşılaştırdığı ve kurs programının zayıflığına işaret ederek geliştirilmesi gerektiği ifade edilmiştir. ${ }^{53}$ Öğreticiler, alana hâkimiyet konusunda kendilerini yeterli görmemektedir. ${ }^{54}$ Korkmaz'ın araştırmasında bu husus meslek sevgisi eksikliği olarak ortaya çıkmıştır. ${ }^{55}$ Alan bilgisinin genelini kapsayan soruların yanı sıra, belli bir konu ya da alan bilgisinin bir alt dalı olarak ifade edilebilecek çalışmalarda da bu eksiklik ortaya çıkmıştır. Nitekim bu kurslar ile ilgili değerler eğitimi çalışmalarını konu alan Acur'un çalışmasında araştırmacılar, değerler eğitimi ile ilgili eksikliklerinin olduğunu ifade etmişlerdir. ${ }^{56}$

İçerik ile ifade edilenlerin yanı sıra kursların program içeriğinde de yaş ve gelişime uygun bir ayrıma gidilmediği hususunun çeșitli problemlere yol açtığına işaret edilmiştir. Bu sebeple bazı çalışmalarda içeriğin 4-5-6 yaşlara göre ayrı ayrı oluşturulmasının önem arz ettiğine ilişkin vurgular yer almaktadır. ${ }^{57}$

\subsection{3. Ĕ̈itim Durumları (Öğrenme-Öğretme Süreci)}

Program geliştirmenin bir öğesi olan eğitim durumları hakkında da öğretici görüşlerine ilişkin veriler barındıran çalışmalar mevcuttur. $\mathrm{Bu}$ anlamda yöntem ve materyal kullanımı, sınıf yönetimi, öğretim sürecini planlama ve özel gereksinimli (özel eğitim) çocukların eğitimine dair görüşler çalışmalarda yer almıştır. Derste nasıl bir yöntem takip edildiği ile ilgili kendisine soru yöneltilen öğreticilerin verdiği cevaplar, yönteme dair bir birikimleri ya da ön bilgileri olsa da, bunu yeterli oranda sahaya yansıtamadıklarını ve bu yönde pedagojik bir donanıma ihtiyaç duyduklarını ortaya koymaktadır. ${ }^{58}$ Öğreticiler, öğrenci merkezli eğitiminden ve bu eğitimin gerekliliğinden haberdardır. Ancak yetişkin kurslarından gelmelerinden ötürü bunu yeterli düzeyde uygulayamadıkları da tespitler arasında yer almaktadir. 59

Öğreticilerin dersleri nasıl işledikleri ile ilgili görüşleri ele alan çalışmalarda yöntem olarak en çok önemsenen ve kullanılanın "anlatım yöntemi" olduğu öne

Gelişim Ödevleri Odaklı Yaklaşım”, Erken Çocukluk Dönemi Din-Ahlak-Değerler Eğitimi ve Sorunları1, ed. Mehmet Bayyiğit, Mehmet Özkan, Ahmet Ali Çanakcı, Asem Hamdy A. Abdelghany, (Konya: Palet Yayınları, 2020), 225.

53 Bayka, Öğretici Ve Veli Görüşleri Açısından Kur’an Kursları Öğretim Programı (4-6 Yaş Grubu)'nın Değerlendirilmesi, 70.

54 Yağcı, Öğreticilere Göre Diyanet İşleri Başkanlığı 4-6 Yaş Grubu Kur'an Kursları (İzmir İli Örneği), 138.

55 Korkmaz, "4-6 Yaș Grubu Kur’an Kursu Öğreticilerinin Eğitim-Öğretim Yeterlikleri Üzerine Bir Araştırma”, 249.

56 Acur, Öğretici Görüşleri Bağlamında Diyanet İșleri Başkanlığı 4-6 Yaş Kur'an Kurslarındaki Değerler Eğitimi Uygulamalarının Değerlendirilmesi, 114.

57 M. Zeki Aydın, Esma Budak, “Diyanet İşleri Başkanlığı 2013 ve 2020 Yılları 4-6 Yaş Grubu Kur’an Kursu Öğretim Programlarının Değerler Eğitimi Açısından İncelenmesi ve Öneriler”, 129; Așlamacı, “4-6 Yaş Kur’an Kursu Öğretim Programının (2018) Eğitim Programı Temel Öğeleri Açısından Değerlendirilmesi”, 147.

58 Zeynep Yüksel, “4-6 Yaş Kur’an Kursu Öğreticilerinin Öğretim Yöntemleri Açısından Yeterlik Algıları (Çankırı Örneği)” Dinî Araştırmalar 24/60 (2021), 156.

${ }^{59}$ Sarı, Kur'an Kursları Öğretici Kitabındaki Uygulamaların İncelenmesi, 90. 
çlkmaktadır. ${ }^{60}$ Öte yandan çeșitli eğitsel oyunlar keşfettikleri ve bu oyunlarla ders işledikleri, drama, canlandırma, öyküleme, soru-cevap gibi yöntem ve teknikleri kullanmaktadırlar. ${ }^{61}$ Öğreticilerin yöntem konusu ile ilgili öğrencilerin seviyesine inmekte zorlandıklarını, ${ }^{62}$ kimi zaman spontane yöntemler kullandıklarını, ${ }^{63}$ deneme-yanılma yolu ile uygun bir yöntem arayarak uygun olanı bulmaya çalıștıklarını $^{64}$ ortaya koyan çalışmalar da mevcuttur. Bunun yanı sıra öğreticilerin dinin soyut konu ve kavramlarını öğretmede yetersizlik yaşadıkları bilgisi de tespitler arasında yer almaktadır. ${ }^{65}$

Eğitim durumları ile ilgili öğretici görüşlerini ele alan çalışmaların üzerinde durduğu önemli bir husus da materyal kullanımıdır. Öğreticilerin materyal ile ilgili sorulara ilahi, müzik, ${ }^{66}$ maket boyama, kukla, ${ }^{67}$ akıllı tahta kullanımı ${ }^{68}$ gibi cevaplar verdikleri araştırmalar mevcuttur. Ancak materyal konusu ile ilgili öğretici görüşlerine yer veren çalışmalarda bütünsel olarak DİB'den gelecek olan materyallere ihtiyaç duyulduğu, bu materyallerin yetersiz olduğu vurgulanmıştır. ${ }^{69}$ Materyal ile ilgili ihtiyaç konusunda sorumluluğun dişarıda aranmasının nedenini bir başka araștırmanın sonucu vermektedir. Öğreticilerin kendilerini materyal geliştirmede

60 Kara, Okul Öncesi Dönemi (4-6 Yaș Grubu) Çocukların Din Eğitiminde Görev Alan Eğitimcilerin/Din Görevlilerinin Pedagojik Yeterlilikleri, 60; Yağcı, Öğreticilere Göre Diyanet İşleri Bașkanlığı 4-6 Yaş Grubu Kur'an Kursları (İzmir İli Örneği), 141; Bayka, Öğretici Ve Veli Görüşleri Açısından Kur'an Kursları Öğretim Programı (4-6 Yaş Grubu)'nın Değerlendirilmesi, 43.

61 Bayka, Öğretici Ve Veli Görüșleri Açısından Kur'an Kursları Öğretim Programı (4-6 Yaş Grubu)'nın Değerlendirilmesi, 43; Kara, Okul Öncesi Dönemi (4-6 Yaş Grubu) Çocukların Din Eğitiminde Görev Alan Eğitimcilerin/Din Görevlilerinin Pedagojik Yeterlilikleri, 60; Acur, Öğretici Görüşleri Bağlamında Diyanet İşleri Başkanlığı 4-6 Yaş Kur’an Kurslarındaki Değerler Eğitimi Uygulamalarının Değerlendirilmesi, 63; Kara, Okul Öncesi Dönemi (4-6 Yaş Grubu) Çocukların Din Eğitiminde Görev Alan Eğitimcilerin/Din Görevlilerinin Pedagojik Yeterlilikleri, 51.

62 Zehra Gelici, “DİB 4-6 Yaş Kur'an Kurslarl, Sorunlar ve Çözüm Önerileri”, Erken Çocukluk Dönemi Din-Ahlak-Değerler Eğitimi ve Sorunları-2, ed. Mehmet Bayyiğit, Mehmet Özkan, Ahmet Ali Çanakcı, Asem Hamdy A. Abdelghany, (Konya: Palet Yayınları, 2020), 148; Yazıbaşı, "Kur'an Kursu Öğreticilerine Göre 4-6 Yaş Kur'an Kursu Öğreticisi, Öğrencisi Ve Öğrenci Velisinin İhtiyaç Ve Beklentileri (Kırıkkale Örneği)", 107.

63 Bayka, Öğretici ve Veli Görüșleri Açısından Kur'an Kursları Öğretim Programı (4-6 Yaş Grubu)’nın Değerlendirilmesi, 43.

${ }^{64}$ Doğan, 4-6 Yaş Grubu Kur’an Kursu Öğreticilerinin Eğitim-Öğretim Yeterlik Algıları (Kayseri Örneği), 58-59.

65 Kara, Diyanet İşleri Başkanlığı 4-6 Yaş Kur'ân Kursu Öğrencilerine Uygulanan Değerler Eğitiminin Öğretici Görüşleri Açısından İncelenmesi, 74.

66 Kara, Okul Öncesi Dönemi (4-6 Yaş Grubu) Çocukların Din Eğitiminde Görev Alan Eğitimcilerin/Din Görevlilerinin Pedagojik Yeterlilikleri, 52.

${ }^{67}$ Karasu, "Kur'an Kursu Öğreticilerine Göre Okul Öncesi Dönemde Din Eğitimi”, 493.

68 Bayka, Öğretici Ve Veli Görüşleri Açısından Kur’an Kursları Öğretim Programı (4-6 Yaş Grubu)’nın Değerlendirilmesi, 43.

69 Bayka, Öğretici ve Veli Görüşleri Açısından Kur'an Kursları Öğretim Programı (4-6 Yaş Grubu)'nın Değerlendirilmesi, 45; Kara, Diyanet İşleri Başkanlı̆̆ı 4-6 Yaș Kur’an Kursu Öğrencilerine Uygulanan Değerler Eğitiminin Öğretici Görüşleri Açısından İncelenmesi, 101; Tüfekçi, Diyanet İşleri Başkanlığı 4-6 Yaș Kur’an Kursları Eğitiminin Öğretici Ve Veli Görüşlerine Göre İncelenmesi, 61; Yağcl, Öğreticilere Göre Diyanet İșleri Başkanlığı 4-6 Yaş Grubu Kur’an Kursları (İzmir İli Örneği), 133; Sarı, Kur’an Kursları Öğretici Kitabındaki Uygulamaların İncelenmesi, 79; Yüksel, “4-6 Yaş Kur’an Kursu Öğreticilerinin Öğretim Yöntemleri Açısından Yeterlik Algıları (Çankırı Örneği)”, 171. 
yetersiz bulduğu, araştırmalara yansımıştır. ${ }^{70}$

Araștırmalarda sınıf yönetimindeki problemlere de işaret edilmektedir. Ödül ve ceza kullanımındaki sorunlar, ${ }^{71}$ ödüle sık yer verme, ${ }^{72}$ çocukların dikkatlerinin çok çabuk dağılmasından ötürü onları bir daha toparlamada yaşanan güçlük, ${ }^{73}$ çocuklar arasındaki şiddeti engelleyememe ${ }^{74}$ gibi durumlar araştırmalara yansımıştır. Öğreticiler sınıf yönetimine dair eksikliklerini ${ }^{75}$ ve bu anlamda pedagojik bir eğitime ihtiyaç duyduklarını ${ }^{76}$ belirtmişlerdir. Öğretim sürecini planlama konusunda da kendilerini yeterli görmedikleri sonucu ortaya çıkmıştır. ${ }^{77}$

Araştırmalarda özel eğitim konusundaki problemlere de işaret edilmektedir. $\mathrm{Bu}$ anlamda öğreticiler, bu çocuklara nasıl davranacaklarını bilmediklerini, ${ }^{78} \mathrm{konu}$ ile ilgili pedagojik yeterliğe sahip olmadıklarını ${ }^{79}$ ileri sürmüşlerdir.

Eğitim durumlarına dair bütün konular, veriler ve öğretici görüşleri incelendiğinde, öğreticilerin eğitim bilimleri ve pedagojik formasyon alanındaki yeterlik algılarının da sınıf ortamındaki başarılarına etki ettiği düşünülmektedir. Bu anlamda öğreticilere soru yönelten çalışmalardan ortaya çıkan ortak nokta, öğreticilerin pedagojik formasyon ile ilgili konularda kendilerini yeterli görmemeleridir. ${ }^{80}$

70 Gelici, “DİB 4-6 Yaș Kur’an Kursları, Sorunlar ve Çözümleri (İstanbul, Üsküdar Örneği)”, 152; Acur, Öğretici Görüşleri Bağlamında Diyanet İşleri Başkanlığı 4-6 Yaş Kur’an Kurslarındaki Değerler Eğitimi Uygulamalarının Değerlendirilmesi, 86.

71 Kara, Okul Öncesi Dönemi (4-6 Yaş Grubu) Çocukların Din Eğitiminde Görev Alan Eğitimcilerin/Din Görevlilerinin Pedagojik Yeterlilikleri 57.

72 Betül Yıldırım, Okul Öncesi Eğitim Kurumlarına Devam Eden 4-6 Yaş Arası Çocuklara Din Eğitimi (Sivas İli Örneği) (Cumhuriyet Üniversitesi, Yüksek Lisans Tezi, 2015), 45.

73 Tüfekçi, Diyanet İşleri Başkanlığı 4-6 Yaş Kuran Kursları Eğitiminin Öğretici Ve Veli Görüşlerine Göre İncelenmesi, 63.

${ }^{74}$ Acur, Öğretici Görüșleri Bağlamında Diyanet İşleri Başkanlığı 4-6 Yaş Kur'an Kurslarındaki Değerler Eğitimi Uygulamalarının Değerlendirilmesi, 100.

75 Korkmaz, "4-6 Yaş Grubu Kur’an Kursu Öğreticilerinin Eğitim-Öğretim Yeterlikleri Üzerine Bir Araștırma”, 250; Acur, Öğretici Görüșleri Bağlamında Diyanet İșleri Bașkanlığı 4-6 Yaș Kur'an Kurslarındaki Değerler Eğitimi Uygulamalarının Değerlendirilmesi, 100; Bayka, Öğretici ve Veli Görüşleri Açısından Kur'an Kursları Öğretim Programı (4-6 Yaş Grubu)'nın Değerlendirilmesi, 54; Sarı, Kur'an Kursları Öğretici Kitabındaki Uygulamaların İncelenmesi, 86.

76 Korkmaz, "4-6 Yaş Grubu Kur’an Kursu Öğreticilerinin Eğitim-Öğretim Yeterlikleri Üzerine Bir Araştırma”, 259.

77 Yüksel, “4-6 Yaş Kur’an Kursu Öğreticilerinin Öğretim Yöntemleri Açısından Yeterlik Algıları (Çankırı Örneği)”, 177.

78 Tüfekçi, Diyanet İşleri Başkanlığı 4-6 Yaş Kuran Kursları Eğitiminin Öğretici ve Veli Görüşlerine Göre İncelenmesi, 63.

${ }^{79}$ Doğan, 4-6 Yaş Grubu Kur’an Kursu Öğreticilerinin Eğitim-Öğretim Yeterlik Algıları (Kayseri Örneği), 135.

80 Mehmet Korkmaz, “04-06 Yaş Kur’an Kurslarında Eğitim Materyali Sorunları ve Öğreticilerin Bu sorunlara Yönelik Çözüm Önerileri”, Erken Çocukluk Dönemi Din-Ahlak-Değerler Eğitimi ve Sorunları-1, ed. Mehmet Bayyiğit, Mehmet Özkan, Ahmet Ali Çanakcl, Asem Hamdy A. Abdelghany, (Konya: Palet Yayınları, 2020), 241; Korkmaz, “4-6 Yaş Grubu Kur’an Kursu Öğreticilerinin EğitimÖğretim Yeterlikleri Üzerine Bir Araştırma”, 249; Aybey, “4-6 Yaş Grubu Kur'an Kurslarının EğitimÖğretim Faaliyetleri Ve Problemleri (Zonguldak İli Örneği)”, 215; Genç, “Diyanet İşleri Başkanlığı'na Bağlı 4-6 Yaş Grubu Kuran Kurslarında Din Eğitimi”, 518; Yazıbașı, "Kur’an Kursu Öğreticilerine Göre 4-6 Yaş Kur’an Kursu Öğreticisi, Öğrencisi Ve Öğrenci Velisinin İhtiyaç Ve Beklentileri (Kırıkkale 
Yani öğreticiler meslekleri ile ilgili gelişmeleri yakından takip etmedikleri, yetersizliklerinin olduğu yönünde görüş bildirerek ${ }^{81}$ böyle bir eğitim almaları gerektiğini ortaya koymuşlardır. ${ }^{82}$ Bunun yanı sıra, öğreticiler çocuk gelişimi ve psikolojisi ile ilgili eksikliklerini de dile getirmişlerdir. ${ }^{83}$ Ancak literatürde bu görüşün aksini ortaya koyan araștırmalar vardır. Mutlu, yaptığı araștırmada Kur'an kursu öğreticilerinin kendilerini yeterli gördüğüne ve mesleki gelişime ihtiyaç hissetmediklerine işaret etmiştir. ${ }^{84}$ Konuya ilişkin çalışmalar, öğreticilerin meslekî yeterliklerinin belirlenmesinde özellikle MEB'in öğretmenlik mesleğinin genel ve özel yeterliklerinden ortaya çıkan tecrübelerinin göz ardı edilmemesi gerektiği hususuna işaret etmektedir. ${ }^{85}$

\subsection{4. Ölçme ve Değerlendirme}

Araştırmalarda öğreticilerin ailelerden gelen geri dönütlere, 86 gözlem yaptıklarına ${ }^{87}$ ve etkinlik sonrası değerlendirmelere ${ }^{88}$ işaret eden görüşlere yer verilmektedir. Kimi araştırmalar öğreticilerin değerlendirme raporları hazırlamadıkları yönünde tespitler ileri sürerken, ${ }^{89}$ bazıları da öğreticilerin yeterli ve pedagojik düzeyde ölçme-değerlendirme bilgisine sahip olmadıklarını ${ }^{90}$ ortaya koymuştur. Ancak salgın döneminde yapılan uzaktan eğitim uygulamalarına ilişkin öğretici görüş-

Örneği)”, 107; Üzümcü, Çınar, “Öğreticilere Göre Diyanet 4-6 Yaş Kur’an Kursları (Çorlu Örneği)”, 29; Gün, "Veli Ve Öğretici Görüșleri Doğrultusunda 4-6 Yaş Grubu Kur'an Kursu Eğitimi”, 62; Yüksel, "4-6 Yaş Kur'an Kursu Öğreticilerinin Öğretim Yöntemleri Açısından Yeterlik Algıları (Çankırı Örneği)", 164; Gelici, "DİB 4-6 Yaş Kur'an Kursları, Sorunlar ve Çözümleri (İstanbul, Üsküdar Örneği)", 155; Kara, Diyanet İșleri Bașkanlığı 4-6 Yaș Kur'ân Kursu Öğrencilerine Uygulanan Değerler Eğitiminin Öğretici Görüşleri Açısından İncelenmesi, 117; Doğan, 4-6 Yaş Grubu Kur'an Kursu Öğreticilerinin Eğitim-Öğretim Yeterlik Algıları (Kayseri Örneği), 180.

${ }^{81}$ Aybey, "4-6 Yaş Grubu Kur’an Kurslarının Eğitim-Öğretim Faaliyetleri Ve Problemleri (Zonguldak İli Örneği)", 216.

82 Üzümcü, Çınar, “Öğreticilere Göre Diyanet 4-6 Yaş Kur’an Kursları (Çorlu Örneği)”, 33; Doğan, 4-6 Yaş Grubu Kur'an Kursu Öğreticilerinin Eğitim-Öğretim Yeterlik Algıları (Kayseri Örneği), 185.

83 Betül Dinçer, Diyanet İșleri Başkanlığı'na Bağlı 4-6 Yaş Okul Öncesi Eğitim Kurumlarında Mevcut Durum ve Beklentilerin Saptanması (Bursa İli Örneği), (Bursa Uludağ Üniversitesi, Yüksek Lisans Tezi, 2020), 68; Korkmaz, 4-6 yaş Grubu Kur'an Kurslarında Din Eğitimi, 130; Korkmaz, "4-6 Yaş Grubu Kur'an Kursu Öğreticilerinin Eğitim-Öğretim Yeterlikleri Üzerine Bir Araștırma”, 249; Kara, Okul Öncesi Dönemi (4-6 Yaş Grubu) Çocukların Din Eğitiminde Görev Alan Eğitimcilerin/Din Görevlilerinin Pedagojik Yeterlilikleri 117; Doğan, 4-6 Yaş Grubu Kur’an Kursu Öğreticilerinin EğitimÖğretim Yeterlik Algıları (Kayseri Örneği), 180.

${ }^{84}$ Şefika Mutlu, "Kur’an Kursu Öğreticilerinin Mesleki Etik İlkelere İlişkin Görüşlerinin Yüksek Din Öğretimine Bakan Yönleri”, Uluslararası Yüksek Din Öğretimi Sempozyumu (Akademik ve Sosyal Yönleriyle) Bildiriler Kitabı, (Malatya: İnönü Üniversitesi Yayınevi, 2019), 165.

85 Üzümcü, “4-6 Yaş Grubu Kur’an Kursu Öğretici Yeterlikleri: Öğretmenlik Mesleği Genel Yeterlikleriyle Karşılaștırmalı Bir Değerlendirme”, 372.

${ }^{86}$ Acur, Öğretici Görüşleri Bağlamında Diyanet İşleri Başkanlığı 4-6 Yaş Kur'an Kurslarındaki Değerler Eğitimi Uygulamalarının Değerlendirilmesi, 108.

87 Bayka, Öğretici Ve Veli Görüşleri Açısından Kur’an Kursları Öğretim Programı (4-6 Yaş Grubu)'nın Değerlendirilmesi, 51.

${ }^{88}$ Sarı, Kur'an Kursları Öğretici Kitabındaki Uygulamaların İncelenmesi, 76.

${ }^{89}$ Yağcı, Öğreticilere Göre Diyanet İșleri Başkanlığı 4-6 Yaş Grubu Kur'an Kursları (İzmir İli Örneği), 141.

${ }^{90}$ Doğan, 4-6 Yaş Grubu Kur’an Kursu Öğreticilerinin Eğitim-Öğretim Yeterlik Algıları (Kayseri Örneği), 141. 
lerine başvuran bir çalışmada, öğreticilerin online eğitim imkânlarını verimli kullandığı ve kazanımlara ulaşma noktasındaki eğitim etkinliklerinde verim elde ettikleri ortaya çıkmıştır. ${ }^{91}$

Program geliştirme öğelerine ilişkin temaya bir bütün olarak bakıldığında programın amaç, içerik, eğitim durumları ve ölçme-değerlendirme unsurlarında öğretici görüşlerinin bazı problemler ortaya çıkardığı görülmüştür. Bu anlamda öğreticilerin amaçlardan yeterli düzeyde haberdar olmadıkları tespit edilmiştir. Program içeriği ile ilgili görüşlerde bu içeriğin öğrencilerin yaş ve gelişim düzeylerine göre tasnif edilmediği, yoğun olduğu ve bu yaş aralığına hitap etme noktasında üst seviyede kaldığı hususu öne çıkmıştır. Ayrıca okul öncesi çağda MEB bünyesinde verilen eğitime kıyasla zayıf olduğu ve geliștirilmesinin önem arz ettiği de vurgulanmıştır. Eğitim durumlarına ilişkin bulgularda öğreticilerin etkili öğretim yöntemleri kullanma, materyal geliştirme veya temin etme, sınıf yönetimi ve özel gereksinimli öğrencilere hitap etme hususlarında eksikliklerinin mevcut olduğu ortaya çıkmıştır. Bu eksiklikler, bir bütün olarak pedagojik formasyon ile ilgili yetersizliklerin mevcut olduğu ve bu yetersizliğin giderilmesinin önem arz ettiği sonucunu ortaya koymaktadır. Ölçme-değerlendirmeye ilişkin veriler ise öğreticilerin pedagojik anlamda uygun ve yeterli bilgiye sahip olmadıklarına ișaretler vardır. 46 yaş aralığında bulunan çocukların gelişim özellikleri düşünüldüğünde, bu kurslarda ölçme ve değerlendirmeye ilişkin gelişim seviyesinin de hesaba katıldığı bir hassasiyetin gerekliliği anlaşılmaktadır.

\subsection{Yapisal Sorunlar}

4-6 yaş grubu Kur'an kurslarına ilişkin yapılan çalışmalardan oluşan çalışma grubunda ortaya çıkan temalardan biri de öğreticilerin karşılaştığı yapısal sorunlardır. Bu sorunlar, şu şekilde sınıflandırılabilir: Yaştan kaynaklı sorunlar, paydaşlardan kaynaklı sorunlar, idareden kaynaklı sorunlar ve kursların fiziksel yapılarından kaynaklı sorunlar.

\subsubsection{Yaştan Kaynaklı Sorunlar}

Bu kursların hitap ettiği yaş grubunun küçük olması, öğrencilerin özel ilgi, beceri ve yeterlik isteyen yaş aralığında olmasından ötürü öğreticilerin görüşlerine yansıyan bazı sorunlar çalıșmalarda yer almıştır. Bu sorunları üç grupta ele alınabilir. Birincisi öğreticilerin iş memnuniyetleri ile ilgilidir. Mesela bir araştırmada öğreticilerin 4-6 yaş grubu ile ilgilenme konusunda sorun yaşadıkları ve dolayısıyla çalışmaya pek istekli olmadıklarına ${ }^{92}$ işaret edilmiştir. Bu durum, bu görüşü taşıyan öğreticilerin söz konusu yaş grubuna hitap edecek yeterlik düzeyinde olmamasını desteklediği gibi, 4-6 yaş grubuna ya da bu kurslara ilgi duymadıkları ile ilgili bir yorumun ileri sürülmesini de mümkün kılabilir.

İkinci sorun ise kursa 4 yaşındaki öğrencilerin de kabul edilmesidir. Araş-

\footnotetext{
91 İbrahim Kurt, "Salgın Döneminde 4-6 Yaş Kur'an Kursları (Ankara Örneği)”, Gümüşhane Üniversitesi İlahiyat Fakültesi Dergisi, 20/2 (2021), 407-408.

92 Muzaffer Üzümcü, Nuran Çınar, "Öğreticilere Göre Diyanet 4-6 Yaș Kur’an Kursları (Çorlu Örneği)", Trabzon İlahiyat Dergisi 7/1 (2020), 28.
} 
tırmalar öğreticilerin 4 yaşın hazırbulunuşluk ve gelişim açısından çok küçük olduğu, bu kurslar için uygun olmadığı yönündeki görüşlerini kaydetmiştir. ${ }^{93}$

Yaş ile ilgili bir diğer sorun ise 4, 5 ve 6 yaşındaki öğrencilerin aynı mekânı paylaşması yani aynı sınıfta olmasıdır. ${ }^{94}$ Bu durum, ders etkinliklerini kimi öğrenciler için fazla kolay, kimileri için de fazla zor görünmesine sebep olabilmektedir. ${ }^{95}$ $\mathrm{Bu}$ konuya dair öğreticilerin önerileri, kitap ve planlamaların her yaş grubu için ayrı ayrı yapılmasına yöneliktir. ${ }^{96}$

\subsubsection{Paydaşlardan Kaynaklı Sorunlar}

Öğretici, öğrenci, program ve veli ile ilgili yapılan incelemelerde öğreticilerin paydaşlarla ilgili sorunları dile getirdikleri görüşler "öğretici" ve "veli" kapsamında bulguların elde edilmesiyle sonuçlanmıştır. Öğretici ile ilgili olarak, çalışmalar bu kursların birer rehber öğretmen ya da psikolojik danışman bulundurmaları gerektiği ile ilgili tespitlerde bulunmuşlardır. Öğreticiler, bu anlamda bir istihdama ihtiyaç duymaktadırlar. ${ }^{97}$ Öte yandan öğreticilerin kurslarda başka yardımcı personel ve öğreticilere ihtiyaç duydukları ile ilgili görüşleri de mevcuttur. ${ }^{98}$

Öğreticilerin veliler ile ilgili görüşlerinde, esas olarak ailenin dinî durum ve bilgilerinin çocuğa yansıdığına ilişkin bir tablo göze çarpmaktadır. ${ }^{99}$ Her ne kadar

93 Gün, "Veli Ve Öğretici Görüşleri Doğrultusunda 4-6 Yaș Grubu Kur’an Kursu Eğitimi”, 44; Aybey, “4-6 Yaş Grubu Kur'an Kurslarının Eğitim-Öğretim Faaliyetleri ve Problemleri (Zonguldak İli Örneği)”, 219; Yağcı, Öğreticilere Göre Diyanet İșleri Başkanlığı 4-6 Yaş Grubu Kur'an Kursları (İzmir İli Örneği), 146; Kara, Okul Öncesi Dönemi (4-6 Yaş Grubu) Çocukların Din Eğitiminde Görev Alan Eğitimcilerin/Din Görevlilerinin Pedagojik Yeterlilikleri, 118; Tüfekçi, Diyanet İşleri Başkanlığı 4-6 Yaș Kuran Kursları Eğitiminin Öğretici Ve Veli Görüșlerine Göre İncelenmesi, 86; Ayar, "4-6 Yaș Grubu Kur'an Kurslarında Elifbâ Öğretimi: Uygulamalar ve Zorlanma Alanları",183.

94 Korkmaz, 4-6 yaș Grubu Kur'an Kurslarında Din Eğitimi, 47; Yıldırım, Okul Öncesi Eğitim Kurumlarına Devam Eden 4-6 Yaş Arası Çocuklara Din Eğitimi (Sivas İli Örneği), 145; Tüfekçi, Diyanet İşleri Başkanlığı 4-6 Yaş Kuran Kursları Eğitiminin Öğretici Ve Veli Görüşlerine Göre İncelenmesi, 86; Ayfer Betül Urduğan, Yusuf Ceylan, “Okul Öncesi Kur’an Kursu Öğretim Programının Program Geliştirme Açısından Değerlendirilmesi”, Erken Çocukluk Dönemi Din-Ahlak-Değerler Eğitimi ve Sorunları-1, ed. Mehmet Bayyiğit, Mehmet Özkan, Ahmet Ali Çanakcı, Asem Hamdy A. Abdelghany, (Konya: Palet Yayınları, 2020), 171.

95 Acur, Öğretici Görüșleri Bağlamında Diyanet İşleri Başkanlığı 4-6 Yaş Kur'an Kurslarındaki Değerler Eğitimi Uygulamalarının Değerlendirilmesi, 81.

96 Aybey, "4-6 Yaş Grubu Kur’an Kurslarının Eğitim-Öğretim Faaliyetleri Ve Problemleri (Zonguldak İli Örneği)”, 237.

97 Muhammed Fatih Genç, “Diyanet İşleri Başkanlığı'na Bağlı 4-6 Yaş Grubu Kuran Kurslarında Din Eğitimi”, İhya Uluslararası İslam Araştırmaları Dergisi, 5/2 (2019), 516; Yağcı, Öğreticilere Göre Diyanet İşleri Başkanlığı 4-6 Yaş Grubu Kur'an Kursları (İzmir İli Örneği), 90-91; Tüfekçi, Diyanet İşleri Başkanlığı 4-6 Yaş Kuran Kursları Eğitiminin Öğretici Ve Veli Görüșlerine Göre İncelenmesi, 85.

98 Yağcl, Öğreticilere Göre Diyanet İșleri Başkanlığı 4-6 Yaş Grubu Kur'an Kursları (İzmir İli Örneği), 95; Yüksel, “4-6 Yaş Kur’an Kursu Öğreticilerinin Öğretim Yöntemleri Açısından Yeterlik Algıları (Çankırı Örneği)”, 171; Arpacı, Soydemir, “DİB'in 4-6 Yaş Grubu Kur'an Kurslarında Din-Ahlak-Değerler Eğitimi Uygulamaları ve Sorunları: Edirne Uygulama Örneği”, 124; Betül Dinçer, Diyanet İşleri Başkanlığı'na Bağlı 4-6 Yaş Okul Öncesi Eğitim Kurumlarında Mevcut Durum ve Beklentilerin Saptanması (Bursa İli Örneği), 72.

99 Şen, 4-6 Yaş Grubu Çocuklarda Kur’an Tasavvuru, 93; Orhan Parlak, Süleyman Şen, “4-6 Yaș Grubu Çocuklarda Kur'an Tasavvurunun Değerlendirilmesi”, Turkish Research Journal of Academic Social Science, 2/1 (2019), 20. 
velilerden alınan dönütler ve bunların eğitim sürecine olumlu katkısı ${ }^{100}$ mevcut olsa da, velilerin yüksek beklentilere sahip oldukları ve kendilerini memnun etme konusunda öğreticilerin sorun yaşadıkları öne çıkmaktadır. ${ }^{101}$ Öte yandan öğreticiler, bu kursların veli potansiyeli olan kamuoyunun yeterli oranda farkındalığa sahip olmadığı görüşünü de taşımaktadırlar. ${ }^{102}$ Öğreticilerin ailelerle iletişim sorunu yaşadıkları araştırmalara yansımıştır. ${ }^{103}$

\subsection{3. İdareden Kaynaklı Sorunlar}

Çalışmalarda öğretici görüşlerine yansıyan sorunlardan biri de, bağlı bulundukları üst idari birimlerdir. Öğreticiler, konu ile ilgili olarak müftülüklerin kendilerini desteklemediklerinden ${ }^{104}$ ve DİB'in öğretici görevlendirme kriterlerinin yanlış olduğundan ${ }^{105}$ yakınmaktadırlar.

Öğreticilerin müftülüklerden ve DİB'den yana sorun yaşadıklarını ileri sürdürdükleri önemli bir konu da hizmet içi eğitim seminerleridir. Konu ile ilgili öncelikle öğreticilerin söz konusu seminerlerin içerik olarak yetersiz, yeterli bilimsel altyapıdan yoksun oldukları görüşleri mevcuttur. ${ }^{106}$ Öte yandan, düzenlenen hizmet içi eğitim seminerlerinin sadece kadrolu öğreticilere yönelik olması, çalışmalara bir rahatsızlık olarak yansımıștır. Zira 4-6 yaş grubu Kur'an kurslarında görev alan öğreticilerin büyük bir kısmı geçici öğreticilerden oluşmaktadır. Bu geçici öğreticilerin seminerlere kabul edilmemesi, öğreticilerin sorun olarak kabul ettikleri bir husustur. ${ }^{107}$ Bunlarla birlikte öğreticiler, pedagojik formasyon ile ilgili eksikliklerinin giderilmesi için hizmet içi eğitim seminerlerine ihtiyaç duyduklarını da ifa-

100 Acur, Öğretici Görüşleri Bağlamında Diyanet İşleri Başkanlığı 4-6 Yaş Kur'an Kurslarındaki Değerler Eğitimi Uygulamalarının Değerlendirilmesi, 108.

101 Genç, "Diyanet İşleri Başkanlı̆̆ı'na Bağlı 4-6 Yaş Grubu Kuran Kurslarında Din Eğitimi”, 516; Yazıbaşı, "Kur'an Kursu Öğreticilerine Göre 4-6 Yaș Kur’an Kursu Öğreticisi, Öğrencisi Ve Öğrenci Velisinin İhtiyaç Ve Beklentileri (Kırıkkale Örneği)”, 110; Tüfekçi, Diyanet İşleri Başkanlığı 4-6 Yaş Kuran Kursları Eğitiminin Öğretici Ve Veli Görüşlerine Göre İncelenmesi, 86; Kara, Okul Öncesi Dönemi (4-6 Yaş Grubu) Çocukların Din Eğitiminde Görev Alan Eğitimcilerin/Din Görevlilerinin Pedagojik Yeterlilikleri, 119; Hatice Ayar, "4-6 Yaş Grubu Kur’an Kurslarında Elifbâ Öğretimi: Uygulamalar ve Zorlanma Alanları" Erken Çocukluk Dönemi Din-Ahlak-Değerler Eğitimi ve Sorunları (Palet Yayınları, Konya 2020), 182.

102 Yağcl, Öğreticilere Göre Diyanet İşleri Başkanlığı 4-6 Yaş Grubu Kur'an Kursları (İzmir İli Örneği), 72; Yüksel, “4-6 Yaş Kur’an Kursu Öğreticilerinin Öğretim Yöntemleri Açısından Yeterlik Algıları (Çankırı Örneği)", 177.

103 Kara, Diyanet İşleri Başkanlığı 4-6 Yaş Kur'ân Kursu Öğrencilerine Uygulanan Değerler Eğitiminin Öğretici Görüşleri Açısından İncelenmesi, 86; Tüfekçi, Diyanet İşleri Başkanlığı 4-6 Yaş Kuran Kursları Eğitiminin Öğretici ve Veli Görüşlerine Göre İncelenmesi, 64.

104 Genç, "Diyanet İşleri Başkanlığı'na Bağlı 4-6 Yaș Grubu Kuran Kurslarında Din Eğitimi”, 516; Acur, Öğretici Görüşleri Bağlamında Diyanet İşleri Başkanlığı 4-6 Yaş Kur’an Kurslarındaki Değerler Eğitimi Uygulamalarının Değerlendirilmesi, 118.

105 Tüfekçi, Diyanet İşleri Başkanlı̆̆ı 4-6 Yaş Kuran Kursları Eğitiminin Öğretici ve Veli Görüșlerine Göre İncelenmesi, 85.

106 Genç, “Diyanet İșleri Başkanlığı'na Bağlı 4-6 Yaş Grubu Kuran Kurslarında Din Eğitimi”, 518; Yağcı, Öğreticilere Göre Diyanet İșleri Başkanlığı 4-6 Yaș Grubu Kur’an Kursları (İzmir İli Örneği), 73.

107 Yağcı, Öğreticilere Göre Diyanet İșleri Bașkanlığı 4-6 Yaș Grubu Kur'an Kursları (İzmir İli Örneği), 81; Doğan, 4-6 Yaş Grubu Kur'an Kursu Öğreticilerinin Eğitim-Öğretim Yeterlik Algıları (Kayseri Örneği), 179. 
de etmiștir. ${ }^{108}$

\subsubsection{Kursların Fiziksel Yapısından Kaynaklı Sorunlar}

Öğretici görüşlerine yansıyan yapısal sorunlardan biri de, kursların fiziksel sorunlarıdır. Bu anlamda incelenen araştırmalarda öğreticiler her ne kadar ulaşım itibarıyla kursların uygun yerlerde açıldığı görüşünü taşısalar da, ${ }^{109}$ açılan bu kursların pek çok fiziksel yetersizlik ve eksikliklerinin olduğunu, bunun da eğitimöğretimi olumsuz etkilediğini ileri sürmüşlerdir. ${ }^{110}$

$\mathrm{Bu}$ fiziksel sorunların hangi alanlar ile ilgili olduğu ise çalışmalarda farklı farklı ortaya konulmuştur. Bu anlamda öğreticiler kurs bahçelerinin, ${ }^{111}$ WC ve lavaboların yetersiz olması ya da çocukların kullanımına uygun olmaması, ${ }^{112}$ kursların sobalı olması ve dolayısıyla ısınma probleminin olması, ${ }^{113}$ çocukların bulundukları yaş itibariyla oyun etkinliklerinin rahat yürütülebileceği uygun bir salonun olmaması, ${ }^{114}$ teknik donanım eksikliğii115 gibi hususlar hakkında görüş ileri sürmüşlerdir.

Yapısal sorunlar temasına ilişkin verilere bir bütün olarak bakıldığında yaştan, paydaşlardan, idareden ve fizikî yapıdan kaynaklı görüşlerin öne çıtığı görülmüştür. Yaş ile ilgili verilerde, bu kursların bünyesine 4 yaşının dâhil edilmesinin uygun olmadığı, her yaş grubunun tasnif edilmeksizin aynı eğitim mekânını paylaşmasının problem teşkil ettiği ve bu konuların bazı meslekî memnuniyetsizliklere yol açtığı tespit edilmiştir. Paydaşlara ilişskin veriler, bu kurslarda rehber öğretmen, psikolojik danışman ve yardımcı personel istihdamının gerekliliği görüşünü ortaya çıkarmıştır. Velilerin de duyarlı olmaları ile beraber, kamuoyunun 4-6 yaş kurslarına ilişkin yeterli düzeyde bilgilendirilmesinin bir ihtiyaç olduğu vurgulanmıştır. İdareden kaynaklı sorunlara ilişkin veriler, öğreticilerin müftülüklerden

108 Yüksel, “4-6 Yaş Kur’an Kursu Öğreticilerinin Öğretim Yöntemleri Açısından Yeterlik Algları (Çankırı Örneği)", 166-167.

109 Yağcl, Öğreticilere Göre Diyanet İşleri Başkanlığı 4-6 Yaş Grubu Kur'an Kursları (İzmir İli Örneği), 102.

110 Gelici, “DİB 4-6 Yaş Kur’an Kursları, Sorunlar ve Çözümleri (İstanbul, Üsküdar Örneği)”, 149-150; Aybey, “4-6 Yaş Grubu Kur’an Kurslarının Eğitim-Öğretim Faaliyetleri Ve Problemleri (Zonguldak İli Örneği)”, 235; Yüksel, “4-6 Yaş Kur’an Kursu Öğreticilerinin Öğretim Yöntemleri Açısından Yeterlik Algıları (Çankırı Örneği)”, 171-172; Yağcı, Öğreticilere Göre Diyanet İşleri Başkanlığı 4-6 Yaş Grubu Kur'an Kursları (İzmir İli Örneği), 114; Yağcı, Samet, "Öğreticilere Göre Diyanet İşleri Başkanlığı ve Müftülüklerin 4-6 Yaş Grubu Kur'an Kursları çalışmaları", Balıkesir İlahiyat Dergisi, 11 (2020), 218; Gün, "Veli Ve Öğretici Görüşleri Doğrultusunda 4-6 Yaş Grubu Kur’an Kursu Eğitimi", 62; Genç, "Diyanet İşleri Başkanlığı'na Bağlı 4-6 Yaş Grubu Kuran Kurslarında Din Eğitimi”, 518; Üzümcü, Çınar, “Öğreticilere Göre Diyanet 4-6 Yaş Kur'an Kursları (Çorlu Örneği)”, 44.

111 Gün, "Veli Ve Öğretici Görüșleri Doğrultusunda 4-6 Yaș Grubu Kur'an Kursu Eğitimi”, 54-55.

112 Aybey, “4-6 Yaș Grubu Kur’an Kurslarının Eğitim-Öğretim Faaliyetleri Ve Problemleri (Zonguldak İli Örneği)”, 235; Gün, "Veli Ve Öğretici Görüşleri Doğrultusunda 4-6 Yaş Grubu Kur'an Kursu Eğitimi”, 54.

113 Korkmaz, 4-6 yaş Grubu Kur'an Kurslarında Din Eğitimi, 92; Gün, "Veli ve Öğretici Görüşleri Doğrultusunda 4-6 Yaş Grubu Kur'an Kursu Eğitimi”, 57.

114 Sarı, Kur’an Kursları Öğretici Kitabındaki Uygulamaların İncelenmesi, 82-83; Bayka, Öğretici ve Veli Görüşleri Açısından Kur'an Kursları Öğretim Programı (4-6 Yaş Grubu)'nın Değerlendirilmesi, 47-48.

115 Sarı, Kur'an Kursları Öğretici Kitabındaki Uygulamaların İncelenmesi, 76. 
daha fazla destek beklediklerini ortaya çıkarmıştır. Yanı sıra öğreticiler, DİB'in hizmetiçi eğitim seminerlerine kadrolu ve sözleşmeli tüm öğreticileri dâhil etmelerini istemekte, bu seminerlerin niteliksel düzeylerini de yeterli görmemektedir. Son olarak öğreticiler, kursların fiziksel koşullarının yetersizliklerine de dikkat çekmekte ve bu koşulların söz konusu yaş aralığının ihtiyaçları göz önünde bulundurularak oluşturulmasının önemini vurgulamaktadır.

\section{Sonuç ve Öneriler}

2014-2015 eğitim-öğretim yılından bugüne tüm Türkiye'de öğrenci kabul eden DİB'e bağlı 4-6 yaş grubu Kur'an kursları ile ilgili öğretici görüşlerine başvuran çalışmaları meta-sentez yöntemini kullanarak inceleyen bu çalışmadaki sonuçlar iki tema altında toplanmıştır. Bu temalar; program geliștirme öğeleri ile yapısal sorunlardır. Program geliştirme öğelerinde amaç, içerik, eğitim durumları ve ölçme-değerlendirme başlıkları ile ilgili ulaşılan sonuçlar, şu şekilde sıralanabilir. Buna göre Kuran kursu öğreticileri:

> Öğretim programı ve bu programın taşıdığı amaçlara yönelik farkındalık sorunu yaşamaktadır.

$>$ Program içeriğinin yoğun olduğunu ve öğrenci kapasitesinin ve hazırbulunuşluğunun üstünde olduğunu düşünmektedir.

> İçeriği oluşturan temel alan bilgisinde yeterlikte sorun yaşamaktadır.

> Dersi etkili bir şekilde işleyebilecek farklı yöntemler hakkında problemler yaşamakta ve uygun araç-gereç, materyal geliştirme ve kullanma konuları bașta olmak üzere, bir bütün olarak pedagojik formasyon, çocuk gelişimi ve psikolojisi konularında zorluklar yaşamakta, eksikliklerini dile getirmektedir.

$>$ Öğretim sürecini değerlendirme konusunda sorunlara işaret etmiştir.

> Eksik olunan noktada gelişme ve eksikliklerin gidermeye ilişkin isteklidir. Yapısal sorunlar ile ilgili ulaşılan sonuçlar, şu şekilde ifade edilebilir: Buna göre öğreticiler:

$>4$ yaşındaki öğrencinin kurslara uygunluğunu tartışmaktadır.

$>$ Sinıflarda 4, 5 ve 6 yaş grubu öğrencilerinin bir arada olmasının sorunlara neden olduğunu ileri sürmektedir.

> Öğretim programının 4, 5 ve 6 yaş gruplarında ayrı ayrı hazırlanması gerektiğini düşünmektedir.

$>$ Kurslarda yardımcı ya da stajyer öğretici ihtiyacı ile ilgili sorunlara işaret etmiştir.

> Çocuk gelişimi ve psikolojisi ile ilgili konularda bir rehber öğretmen ya da psikolojik danışmanın istihdam edilmesi gerektiğini düşünmektedir.

$>$ DİB'in, öğreticilere yönelik hizmet içi eğitim seminerlerinin artırılmasına ve niteliğinin geliştirilmesine dikkat çekmiştir. Bunun yanı sıra söz konusu seminerlerin bütün öğreticileri kapsaması gerektiğini de belirtmiştir.

> Kursların fiziksel yapıları ve donanımının, 4-6 yaş grubuna uygunluğu ile ilgili sorunlara işaret etmiştir.

Kur'an Kursu öğreticileri ile yapılan çalışmalardaki sorunların iki kaynağı olduğu söylenebilir. Bunlardan birincisi kaynak program olan ilahiyat fakültesi diğeri ise istihdam eden kurum olan DİB. Kur'an Kursu öğreticilerinin kaynak 
programları olan İmam-Hatip Liseleri (İHL)/İlahiyat Fakültelerinin istihdam merkezli bölümleşmesinin veya programlarının olmamasının bu sorunların önemli bir kaynağını teșkil ettiği söylenebilir. Nitekim yapılan çalışmalarda da bu duruma işaret edilmekte ve çeşitli çözüm önerileri geliştirilmektedir. ${ }^{116}$ İlahiyat fakültelerinde istihdam merkezli bölümlerin ihdas edilmesinin yanı sıra ilahiyatın mevcut halinin korunması ve DİB'in istediği personeli kendi kurumu bünyesinde yetiștirmesi yönündedir. İlahiyat programlarında da 4-6 Kur'an kursları için değil Kur'an kursu öğreticisi olmak için dahi mesleki dersler bulunmamaktadır. Bu ihtiyaç ancak bazı ilahiyat fakültelerinin seçmeli dersleri ile karşılanmaya çalışılmaktadır. Gün geçtikçe gelişen din hizmetlerine kaynak programların ayak uyduramaması sahada önemli sorunlara neden olmakta ve bu sorunlar öğreticileri merkeze alan çalışmalarda belirmektedir. İlahiyat fakülteleri için böyle bir sorunun varlığı göz önünde bulundurulunca hâlâ diğer bir kaynak program olarak tasarlanan İHL veya önlisans ilahiyat eğitiminin bu çerçevede değerlendirilmesi düşündürücüdür.

Tevhid-i Tedrisat Kanunu Türkiye'de eğitimi tek bir merkezde toplamakta ve bu durum başka kurumların örgün eğitim yapmalarına müsaade etmemektedir. Bu durum 4-6 yaş Kur'an kurslarının yapısal sorunlarının çözümü önünde bir engel olarak düşünülebilir. Yani kurslar okul olarak düşünülememektedir. Bu da atılacak birçok adıma ket vurmakta ve bu kurumların gelişmesi önünde bir engel olarak durmaktadır. Kurumların Kur'an kursu olarak isimlendirilmesi de uygulamanın önündeki engellerden biridir. Nitekim DİB bünyesinde birçok Kur’an kursu türü bulunmaktadır. Bunlar arasında hafızlık, ihtiyaç odaklı, yaz Kur'an kursları vb. sayılabilir. Bu kurumların ortaya çıkış nedenleri, fiziki mekânları, idaresi ve kurumlarda çalışanlar arasındaki ilişkiler farklılaşmaktadır. Bunların yanı sıra kurumlardaki görevliler, en azından din hizmeti verilen bireyler açısından farklı farklı yeterliklere sahip olmalıdırlar. Yani bir yetişkinin dinî gelişimi ile ergenlik dönemindeki bireyin dinî gelişimleri farklılaşmakta, bu durum da din hizmetinin niteliğinin değişmesini gerektirmektedir. Böyle olduğu hâlde DİB, Kur'an kursu öğreticileri için yeterlik belirlerken özel alan yeterlikleri belirlememiş, toptancı bir anlayışla bütün Kur'an kursu öğreticileri için yeterlikler belirlemiştir. ${ }^{117}$

Elde edilen sonuçlardan hareketle, DİB'e ve konuya ilgi duyan araştırmacılara çeşitli öneriler sunulabilir. Bu anlamda DİB'e sunulabilecek öneriler şunlardır:

- Mevcut öğreticilerin alan bilgisi, pedagojik formasyon ve gelişim psikolojisi ile ilgili eksikliklerini gidermek amacıyla çeşitli hizmet içi eğitim seminerleri hazırlanabilir, bazı etkinlik ve programlar için MEB ile koordineli çalışmalar için girişimlerde bulunulabilir.

- Öğretici istihdamı ile ilgili gelecek planlamasında ideali yakalamak adına

116 İbrahim Turan, “Türkiye’de İlahiyat Eğitimi: İstihdam Alanı-Program İlişkisi Üzerine Bir Değerlendirme”, İstanbul Üniversitesi İlahiyat Fakültesi Dergisi, 37 (2017), 74-76; Tahsin Görgün, "Türk Üniversitesi ve Dinî İlimler İlahiyatın Akademik Yapılanması, Bölümleri ve Anabilim Dalları Nasıl Olmalıdır?”, Bugünün İlahiyatı Nasıl Olmalıdır? -Sorunlar ve Çözümleri- Tartışmalı İlmi İhtisas Toplantısı, (İstanbul: 2015), 203.

117 Diyanet İșleri Başkanlığı (DİB), “Diyanet İşleri Başkanlığı Personel Yeterlikleri” (Erişim: 18 Eylül 2021). 
üniversiteler ile çift anadal ve yandal konularında görüşmeler yapılabilir, protokol girişimlerinde bulunulabilir.

- Öğretim programının içerik boyutu yeniden değerlendirilebilir.

- Kurslarda öğretici dışında hem idari hem de rehberlik yönünden yeni istihdam olanakları düşünülebilir. Yardımcı personel ile ilgili sorunlara yönelik çeşitli önlemler alınabilir.

- Kurslara kabul şartları gözden geçirilebilir.

- Kursların fiziki şartlarını düzenleyici önlemler alınabilir.

- Kamuoyuna sistematik olarak basın ve yayın aracılığıla bu kurslara duyulan ihtiyaç, kursların önemi, pedagojik yapısı ve gelişim seviyesine uygunluğu gibi hususları içeren bilgilendirme çalışmaları yapılabilir.

Konuya ilgi duyan araştırmacılara sunulabilecek öneriler ise şunlardır:

- Kurslardaki öğretim uygulamalar gözlem yoluyla çalışılabilir.

- Çeşitli yöntemlerin etkin kullanımına dair deneysel desenli çalışmalar yapılabilir.

- Kurslarda özel eğitim konusunda yaşanan sorunlarla ilgili betimsel ve çözüm önerisi sunan çalışmalar ele alınabilir.

Author Contributions / Yazarların Katkısı: In the each of th conceptualization, metodology, software, investigation, writing review, editing and discussion processes, each author's contribution rate is 50\%. / Kavramsallaştırma, metodoloji, yazılım, araştırma, metin taslağının hazırlanması, metnin yazılması ve tartışma süreçlerinin her birinde, her bir yazarın katkı oranı \%50'dir

Funding / Finansman: This research received no external funding. / Bu araștırma herhangi bir dış fon almamıştır.

Conflicts of Interest / Çıkar Çatışması: The author declare no conflict of interest. / Yazar, herhangi bir çıkar çatışması olmadığını beyan eder.

Kaynakça

Acur, Elif. Öğretici Görüşleri Bağlamında Diyanet Ișsleri Başkanlığı 4-6 Yaş Kur'an Kurslarındaki Değerler Eğitimi Uygulamalarının Değerlendirilmesi. Sakarya: Sakarya Üniversitesi, Yüksek Lisans Tezi, 2019.

Arpacı, Önder, Soydemir, Fatma. "DİB'in 4-6 Yaş Grubu Kur'an Kurslarında Din-AhlakDeğerler Eğitimi Uygulamaları ve Sorunları: Edirne Uygulama Örneği". Erken Çocukluk Dönemi Din-Ahlak-Değerler Eğitimi ve Sorunları-2. ed. Mehmet Bayyiğit, Mehmet Özkan, Ahmet Ali Çanakcl, Asem Hamdy A. Abdelghany. 121-131. Konya: Palet Yayınları, 2020.

Aşlamacı, İbrahim. "4-6 Yaș Kur’an Kursu Öğretim Programının (2018) Eğitim Programı Temel Öğeleri Açısından Değerlendirilmesi”. Erken Çocukluk Dönemi Din-AhlakDeğerler Eğitimi ve Sorunları-1. ed. Mehmet Bayyiğit, Mehmet Özkan, Ahmet Ali Çanakcl, Asem Hamdy A. Abdelghany. 138-148. Konya: Palet Yayınları, 2020.

Ayar, Hatice. "4-6 Yaş Grubu Kur’an Kurslarında Elifbâ Öğretimi: Uygulamalar ve Zorlanma Alanları". Erken Cocukluk Dönemi Din-Ahlak-Değerler Eğitimi ve Sorunları-2. ed. Mehmet Bayyiğit, Mehmet Özkan, Ahmet Ali Çanakcl, Asem Hamdy A. Abdelghany. 161-186. Konya: Palet Yayınları, 2020.

Aydın, M. Zeki, Budak, Esma. "Diyanet İşleri Başkanlığı 2013 ve 2020 Yılları 4-6 Yaş Grubu Kur'an Kursu Öğretim Programlarının Değerler Eğitimi Açısından İncelenmesi ve Öneriler". Erken Çocukluk Dönemi Din-Ahlak-Değerler Eğitimi ve Sorunlarl-1. ed. 
Mehmet Bayyiğit, Mehmet Özkan, Ahmet Ali Çanakcl, Asem Hamdy A. Abdelghany. 119-136. Konya: Palet Yayınları, 2020.

Ayhan, Halis. Türkiye'de Din Eğitimi. İstanbul: DEM Yayınları, 2014.

Aybey, Salih. "4-6 Yaș Grubu Kur'an Kurslarının Eğitim-Öğretim Faaliyetleri Ve Problemleri (Zonguldak İli Örneği)". Bülent Ecevit Üniversitesi İlahiyat Fakültesi Dergisi. 6/2 (2019) 207-240. https://doi.org/10.33460/beuifd.598401.

Bayka, Hatice. Öğretici ve Veli Görüşleri Açısından Kur'an Kursları Öğretim Programı (4-6 Yaş Grubu)'nın Değerlendirilmesi. Samsun: Ondokuz Mayıs Üniversitesi, Yüksek Lisans Tezi, 2019.

Bondas, Terese, Hall, Elisabeth O. C. "Challenges In Approaching Metasyntesis Research". Qualitative Health Research. 17/1 (2007) 113-121.

Buhârî, Ebu Abdullah Muhammed b. İsmail. Sahîhu'l-Buhârî. Dımaşk: Daru İbn Kesîr, 2002.

Campbell R., Pound P., Morgan, M, Daker-White, G., Britten, N., Pill, R., Yardley, L., Pope, C., Denovan, J. "Evaluating Meta-Ethnography Systematic Analysis And Synthesis of Qualitative Research". Health Technology Assesment. 15/43 (2011) 1-180.

Çalık, Muammer, Sözbilir, Mustafa. "Parameters Of Content Analysis". Education And Science. 39/174 (2014) 33-38.

Çelebi, Ahmet. İslam'da Eğitim-Öğretim Tarihi. İstanbul: Damla Yayınevi, 2013.

DİB, Diyanet İşleri Başkanlığı. “Diyanet İşleri Başkanlığı Kur'an Eğitim Ve Öğretimine Yönelik Kurslar Ve Öğrenci Yurt Ve Pansiyonları Yönergesi”. Erișim: 1 Ekim 2020, https://www.mevzuat.gov.tr/File/GeneratePdf?mevzuatNo=16041\&mevzuatTur=K urumVeKurulusYonetmeligi\&mevzuatTertip=5.

DİB, Diyanet İşleri Başkanlığı. “Diyanet İşleri Başkanlığı Personel Yeterlikleri”. Erişim: 18 Eylül

https://hukukmusavirligi.diyanet.gov.tr/Documents/Diyanet\%20\%C4\%B0\%C5\%9

Fleri\%20Ba\%C5\%9Fkanl\%C4\%B1\%C4\%9F\%C4\%B1\%20Personel\%20Yeterlikleri. pdf.

DİB, Diyanet İșleri Başkanlığı. "Faaliyet Raporu 2013". Erișim: 1 Ekim 2020, https://stratejigelistirme.diyanet.gov.tr/Documents/2013\%20Yılı\%20Faaliyet\%20 Raporu.pdf.

DİB, Diyanet İşleri Başkanlığl. "Faaliyet Raporu 2014". Erişim: 1 Ekim 2020, https://stratejigelistirme.diyanet.gov.tr/Documents/2014\%20Yllı20Faaliyet\%20 Raporu.pdf.

DİB, Diyanet İșleri Başkanlığı. "Faaliyet Raporu 2015". Erişim: 1 Ekim 2020, https://stratejigelistirme.diyanet.gov.tr/Documents/2015\%20Yılı\%20Faaliyet\%20 Raporu.pdf.

DİB, Diyanet İşleri Başkanlığı. "Faaliyet Raporu 2017". Erişim: 1 Ekim 2020, https://stratejigelistirme.diyanet.gov.tr/Documents/2017\%20Yılı\%20Faaliyet\%20 Raporu.pdf.

DİB, Diyanet İşleri Başkanlığı. "Faaliyet Raporu 2018”. Erişim: 1 Ekim 2020, https://stratejigelistirme.diyanet.gov.tr/Documents/2018\%20İdare\%20Faaliyet $\% 2$ 0Raporu.pdf.

DİB, Diyanet İşleri Başkanlığı. "Faaliyet Raporu 2019". Erişim: 1 Ekim 2020, https://stratejigelistirme.diyanet.gov.tr/Documents/2019\%20Yılı\%20Faaliyet\%20 Raporu.pdf.

DỉB, Diyanet İșleri Başkanlığı. "Faaliyet Raporu 2020". Erişim: 11 Eylül 2021, https://stratejigelistirme.diyanet.gov.tr/Documents/2020\%20.

DỉB, Diyanet İşleri Başkanlığı. "Kur'an Kursları Öğretim Programı (4-6 Yaş Grubu)”. Erișim: 1

Ekim 2020, https://egitimhizmetleri.diyanet.gov.tr/Documents/Kur'an\%20Kursları\%20Öğreti m\%20Programı\%20(4-6\%20Yaş\%20Grubu)\%202018.pdf.

DİB, Diyanet İşleri Başkanlığı. Kur'an'ı Kerîm. Erişim: 29 Eylül 2020, https://kuran.diyanet.gov.tr/mushaf. 
Diler, Ramazan. "4-6 Yaș Kur’an Kursu Öğreticilerine Göre Mahremiyet Eğitimi ve Önemi (Nitel Bir Analiz)", Eskiyeni 41 (2020) 623-652. https://doi.org/10.37697/eskiyeni.734877.

Dinçer, Betül. Diyanet İşleri Başkanlı̆̆ı'na Bağlı 4-6 Yaş Okul Öncesi Eğitim Kurumlarında Mevcut Durum ve Beklentilerin Saptanması (Bursa İli Örneği). Bursa: Bursa Uludağ Üniversitesi, Yüksek Lisans Tezi, 2020.

Dinçer, Serkan. "Content Analysis In For Educational Science Research: Meta Analysis, MetaSynthesis, And Descriptive Content Analysis", Bartın University Journal of Faculty of Education 7/1 (2018) 176-190.

Doğan, Zülfi. 4-6 Yaş Grubu Kur'an Kursu Öğreticilerinin Eğitim-Öğretim Yeterlik Algıları (Kayseri Örneği). Kayseri: Erciyes Üniversitesi, Yüksek Lisans Tezi, 2019.

Dam, Hasan. "Çocukluk Dönemi Din Eğitimi”. Gelişimsel Basamaklarına Göre Din Eğitimi. ed. Mustafa Köylü, Ankara: Nobel Yayınları, 2013.

Dündar, Mahmut. İlk Dönem İslami Eğitim-Öğretim Faaliyetleri. İstanbul: İșrak Yayınları, 2011.

Ebû Davûd, Süleyman b. el-Eş'as b. İshak b. Beşîr el-Ezdî es-Sicistânî. Süneni Ebî Davûd. thk. Raid b. Sabri İbn Ebî ‘Alfe, Riyad: Daru’l-Hadara, 2015.

Gelici, Zehra. "DİB 4-6 Yaş Kur’an Kurslarl, Sorunlar ve Çözümleri (İstanbul, Üsküdar Örneği)". Erken Cocukluk Dönemi Din-Ahlak-Değerler Eğitimi ve Sorunları. ed. Mehmet Bayyiğit, Mehmet Özkan, Ahmet Ali Çanakcl, Asem Hamdy A. Abdelghany. 143-160. Konya: Palet Yayınları, 2020.

Genç, Muhammed Fatih. “Diyanet İșleri Bașkanlığı'na Bağlı 4-6 Yaș Grubu Kuran Kurslarında Din Eğitimi”. Ihyya Uluslararası İslam Araştırmaları Dergisi. 5/2 (2019) 506-521.

Görgün, Tahsin. "Türk Üniversitesi ve Dinî İlimler İlahiyatın Akademik Yapılanması, Bölümleri ve Anabilim Dalları Nasıl Olmalıdır?". Bugünün İlahiyatı Nasıl Olmalıdır? Sorunlar ve Çözümleri. 149-164. İstanbul 2015.

Gözütok, Şakir. İlk Dönem İslam Eğitim Tarihi. Ankara: Fecr Yayınları, 2002.

Gücen, Ali, Çakmak, Ahmet, Ay, Mustafa Fatih. "4-6 Yaş Kur’an Kursu Öğretim Programının Öğretici Görüşleri Çerçevesinde Değerlendirilmesi”. Uluslararası Erken Çocukluk Dönemi Kongresi Bildiri Kitabı. ed. Mücahit Kıbrıs. 752-765. İstanbul: İstanbul Büyükșehir Belediyesi, 2016.

Gül, Tuba. 4-6 Yaş Dönemi Çocuklarda Merhamet Eğitimi. Konya: Necmettin Erbakan Üniversitesi Sosyal Bilimler Enstitüsü, Yüksek Lisans Tezi, 2019.

Gün, Ayșegül. "Veli ve Öğretici Görüşleri Doğrultusunda 4-6 Yaş Grubu Kur'an Kursu Eğitimi". Amasya Üniversitesi İlahiyat Fakültesi Dergisi. 7 (2016) 33-66. https://doi.org/10.18498/amauifd.282862.

Hızlı, Mefail. “Osmanlı Döneminde Bir İlköğretim Kurumu Olarak Sıbyan Mektepleri”, Íslam Tarihinin Problemleri Kolokyumu. Şanlıurfa: Elif Matbaası, 2008.

Hökelekli, Hayati. Din Psikolojisi. Ankara: Türkiye Diyanet Vakfı Yayınları, 1998.

Kara, Büşra. Okul Öncesi Dönemi (4-6 Yaş Grubu) Çocukların Din Eğitiminde Görev Alan Ĕgitimcilerin/Din Görevlilerinin Pedagojik Yeterlilikleri. Bursa: Uludağ Üniversitesi, Yüksek Lisans Tezi, 2019.

Karaca, Ayșe Sevde. DỉB 4-6 Yaş Kur'an Kursu Öğrencilerine Uygulanan Değerler Eğitiminin Öğretici Görüşleri Açısından İncelenmesi. Konya: Necmettin Erbakan Üniversitesi, Yüksek Lisans Tezi, 2020.

Karasu, Teceli. "Kur’an Kursu Öğreticilerine Göre Okul Öncesi Dönemde Din Eğitimi: Muş İli Örneği". Illahiyat Tetkikleri Dergisi. 51 (2019), 479-500. https://doi.org/10.29288/ilted.495961.

Korkmaz, Mehmet. "04-06 Yaş Kur’an Kurslarında Eğitim Materyali Sorunları ve Öğreticilerin Bu sorunlara Yönelik Çözüm Önerileri”. Erken Çocukluk Dönemi DinAhlak-Değerler Eğitimi ve Sorunları-1. ed. Mehmet Bayyiğit, Mehmet Özkan, Ahmet Ali Çanakcı, Asem Hamdy A. Abdelghany. 229-243. Konya: Palet Yayınları, 2020.

Korkmaz, Mehmet. 4-6 yaş Grubu Kur'an Kurslarında Din Eğitimi. Kayseri: Kimlik Yayınları Marife 21/2 (2021): 803-831 
2019.

Korkmaz, Mehmet. "4-6 Yaș Grubu Kur'an Kursu Öğreticilerinin Eğitim-Öğretim Yeterlikleri Üzerine Bir Araștırma”. İlahiyat Tetkikleri Dergisi. 53 (2020) 237-261. https://doi.org/10.29288/ilted.679601.

Kurt, İbrahim. "Salgın Döneminde 4-6 Yaș Kur’an Kursları (Ankara Örneği)”, Gümüşhane Üniversitesi İlahiyat Fakültesi Dergisi. 20/2 (2021) 393-421.

Kurt, İbrahim. Velilerin 4-6 Yaş Kur'an Kurslarından Memnuniyet Düzeyleri ve Beklentileri Üzerine Bir Araștırma (Ankara Örneği). Çorum: Hitit Üniversitesi Sosyal Bilimler Enstitüsü, Yüksek Lisans Tezi, 2017.

Makdisi, George. Ortaçağ’da Yüksek Öğretim. çev. Ali hakan Çavuşoğlu, Tuncay Başoğlu, İstanbul: Klasik Yayınları, 2015.

Mutlu, Şefika. "Kur'an Kursu Öğreticilerinin Meslekî Etik İlkelere İlişkin Görüşlerinin Yüksek Din Öğretimine Bakan Yönleri”. Uluslararası Yüksek Din Öğretimi Sempozyumu (Akademik ve Sosyal Yönleriyle) Bildiriler Kitabı, 149-168. Malatya: İnönü Üniversitesi Yayınları 2019.

Müslim, Ebu'l-Hüseyn Müslim. Sahîhu Müslim. Riyad: Daru's-Selâm, 2000.

Newberg, Andrew B., Newberg Stephanie K. "Dinî Ve Manevî Tecrübenin Nöropsikolojisi". çev. Şeyma Turan. Din ve Maneviyat Psikolojisi. ed. İhsan Çapçığlu, Ali Ayten, Ankara: Phoenix Yayınevi, 2013.

Noblit, George W. "Meta-Etnography: Adoptation And Return". Cultural Constructions Of Identity. ed. Luis Urrieta, George W. Noblit. New York: Oxford University Press, 2018.

Öcal, Mustafa. "Cumhuriyet Döneminde Türkiye'de Din Eğitimi ve Öğretimi", Uludă̆ Üniversitesi İlahiyat Fakültesi Dergisi 7 (1998), 241-268.

Öztürk, Osman. "Basic Principles Of Primary Schools Education İn Ottoman Empire". Íslam Tetkikleri Enstitüsü Dergisi, 6/1-2 (1978) 213-220.

Parlak, Orhan, Şen, Süleyman. "4-6 Yaş Grubu Çocuklarda Kur'an Tasavvurunun Değerlendirilmesi", Turkish Research Journal of Academic Social Science, 2/1 (2019) 14-23. https://doi.org/10.33718/tid.712965.

Pazarlı, Osman. Din Psikolojisi. İstanbul: Remzi Kitabevi, 1982.

Polat, Seyat, Ay, Osman. "Meta-Sentez: Kavramsal Bir Çözümleme”, Eğitimde Nitel Araştırmalar Dergisi 4/1 (2016) 52-64.

Sağlam, İsmail. "Kur'an Kursları 4-6 Yaş Din Eğitimi Projesi Hikâyesi ve Mevcut Durum". Erken Çocukluk Dönemi Din-Ahlak-Değerler Eğitimi ve Sorunlarl-2. ed. Mehmet Bayyiğit, Mehmet Özkan, Ahmet Ali Çanakcl, Asem Hamdy A. Abdelghany. 2-19. Konya: Palet Yayınları, 2020.

Sarı, Bekir. Kur'an Kursları Öğretici Kitabındaki Uygulamaların İncelenmesi. Erzurum: Atatürk Üniversitesi, Yüksek Lisans Tezi, 2019.

Şen, Süleyman. 4-6 Yaş Grubu Çocuklarda Kur'an Tasavvuru. Uşak: Uşak Üniversitesi Sosyal Bilimler Enstitüsü, Yüksek Lisans Tezi, 2018.

Tarhan, Nevzat. İnanç Psikolojisi. İstanbul: Timaş Yayınları, 2014.

Tosun, Cemal. "Okulöncesi Din Eğitiminin Psikolojik Temellerinin Önemi: 4-6 Yaș Din Eğitimine Gelişim Ödevleri Odaklı Yaklaşım". Erken Çocukluk Dönemi Din-AhlakDeğerler Eğitimi ve Sorunları-1. ed. Mehmet Bayyiğit, Mehmet Özkan, Ahmet Ali Çanakcl, Asem Hamdy A. Abdelghany. 224-228. Konya: Palet Yayınları, 2020.

Turan, İbrahim. "Türkiye'de İlahiyat Eğitimi: İstihdam Alanı-Program İlişkisi Üzerine Bir Değerlendirme”. İstanbul Üniversitesi İlahiyat Fakültesi Dergisi. 37 (2017) 59-77. http://dx.doi.org/10.26650/ilahiyat.2017.19.2.0014.

Tüfekçi, Kevser. Diyanet Isşleri Başkanlığı 4-6 Yaş Kur'an Kursları Eğitiminin Öğretici ve Veli Görüşlerine Göre İncelenmesi. Gaziantep: Gaziantep Üniversitesi Eğitim Bilimleri Enstitüsü, Yüksek Lisans Tezi, 2020.

Urduğan, Betül, Ceylan, Yusuf. "Okul Öncesi Kur'an Kursu Öğretim Programının Program Geliştirme Açısından Değerlendirilmesi”. Erken Çocukluk Dönemi Din-Ahlak-Değerler Eğitimi ve Sorunları-1, ed. Mehmet Bayyiğit, Mehmet Özkan, Ahmet Ali Çanakcı, Asem Hamdy A. Abdelghany. 159-172. Konya: Palet Yayınları, 2020. 
Üzümcü, Muzaffer. “4-6 Yaş Grubu Kur’an Kursu Öğretici Yeterlikleri: Öğretmenlik Mesleği Genel Yeterlikleriyle Karşılaștırmalı Bir Değerlendirme". Erken Çocukluk Dönemi DinAhlak-Değerler Eğitimi ve Sorunları-1, ed. Mehmet Bayyiğit, Mehmet Özkan, Ahmet Ali Çanakcl, Asem Hamdy A. Abdelghany. 365-373. Konya: Palet Yayınları, 2020.

Üzümcü, Muzaffer, Çınar, Nuran. “Öğreticilere Göre Diyanet 4-6 Yaş Kur’an Kursları (Çorlu Örneği)”. $\quad$ Trabzon Ilahiyat Dergisi. 7/1 (2020) 7-51. https://doi.org/10.33718/tid.712965.

Walsh, Denish, Downe, Soo. "Meta-Synthesis Method For Qualitative Research: A Literature Review". Journal Of Advanced Nursing. 50/2 (2005) 204-211.

Yağcl, Samet. "Öğreticilere Göre Diyanet İşleri Başkanlığı ve Müftülüklerin 4-6 Yaş Grubu Kur'an Kursları Çalışmaları". Balıkesir İlahiyat Dergisi, 11 (2020) 195-221.

Yağcı, Samet. Öğreticilere Göre Diyanet Isşleri Başkanlığı 4-6 Yaş Grubu Kur'an Kursları (İzmir İli Örneği). İzmir: İzmir Katip Çelebi Üniversitesi, Yüksek Lisans Tezi, 2018.

Yazibaşi, Muhammed Ali. “Kur’an Kursu Öğreticilerine Göre 4-6 Yaş Kur’an Kursu Öğreticisi, Öğrencisi Ve Öğrenci Velisinin İhtiyaç Ve Beklentileri (Kırıkkale Örneği)". Dini Araștırmalar. 23/57 (2020), 95-116. https://doi.org/10.15745/da.749609.

Yavuz, Kerim. Çocukta Dinî Duygu ve Düşüncenin Gelişmesi. İstanbul: Boğaziçi Yayınları, 2012.

Yıldırım, Betül. Okul Öncesi Eğitim Kurumlarına Devam Eden 4-6 Yaş Arası Cocuklara Din Eğitimi(Sivas İli Örneği). Sivas: Cumhuriyet Üniversitesi, Yüksek Lisans Tezi, 2015.

Yüksel, Zeynep. "4-6 Yaş Kur’an Kursu Öğreticilerinin Öğretim Yöntemleri Açısından Yeterlik Algıları (Çankırı Örneği)" Dinî Araştırmalar 24/60 (2021), 147-179. https://doi.org/10.15745/da.907866.

Zimmer, Lela. "Qualitative Meta-Synthesis: A Question Of Dialoguing With Nexts". Journal of Advanced Nursing. 53/3 (2006) 311-318. 